Please do not circulate or cite without permission of the author.

\title{
Why do allies receive less foreign aid than non-allies?
}

\author{
Qi Zhang
}

\begin{abstract}
Traditionally, scholars believe that formal defense alliance increases foreign aid allocation. However, this paper finds since the 1970s, OECD donors have been increasing their development assistance to non-allies, and by mid-2000s, the average amount of aid allocated to non-allies has surpassed that of allies. What explains this changing pattern of alliance and foreign aid allocation? This paper argues that alliance's impact on foreign aid is conditional on the global security environment, defined as the sum of hostility and insecurity between all states in the system. When the security environment is competitive, donors need to provide aid to allies to strengthen the alliance and support friendly regimes. When the security environment is favorable, donors could use alliance membership as an incentive to solicit policy concessions from aspiring members. Alliance can save donors' budgets through attraction and substitution mechanisms. This paper contributes to the debate on the cost of alliances by showing that alliances can reduce the financial burden of the leading state. Additionally, this paper theorizes changes in foreign aid policies by incorporating the system as a moderating variable. It will test the hypothesis with two-way fixed effect models and various robustness checks using foreign aid data from 1960 to 2013.
\end{abstract}


Please do not circulate or cite without permission of the author.

\section{INTRODUCTION}

The foreign aid and alliance policies of the United States are under a heated debate. In September 2018, President Donald Trump of the United States said that the US should only give aid to allies and friends and countries that supported its foreign policies.1 In numerous occasions since 2017, he has also reiterated accusations that allies were free riding on the US 2 . President Trump's comments ignite the old theoretical questions: what drives foreign aid allocation, and what is the relationship between foreign aid and alliance. The academic answer to these questions seems straightforward. There is a large consensus among foreign aid scholars that political considerations rather than humanitarian needs shapes foreign aid allocation, and strategic recipients such as allies and trade partners receive more aid than other countries.

However, the latest aid allocation data shows that allies, on average, do not receive more aid than non-allies. The United States is increasingly offering development assistance to nonallies, while allies have been experiencing either an aid cut or a stagnation for decades, even if we exclude developed countries and those that are no longer eligible to receive official development assistance (see Figure 1). Since 2000, the US has, on average, provided more economic aid to non-allies, and since 2008, the US has been offering more economic and military aid to non-allies than to receiving countries that are American allies. The US is not merely an exception. The foreign aid allocation of other major donors--France, the United Kingdom, and Germany, also follows a similar pattern (Figure 2). Allies of these countries received many times more aid than non-allies until the early 2000s, when their aid plumped. In comparison, these donors have been increasing their aid to non-allies except for the early years of the 1990s.
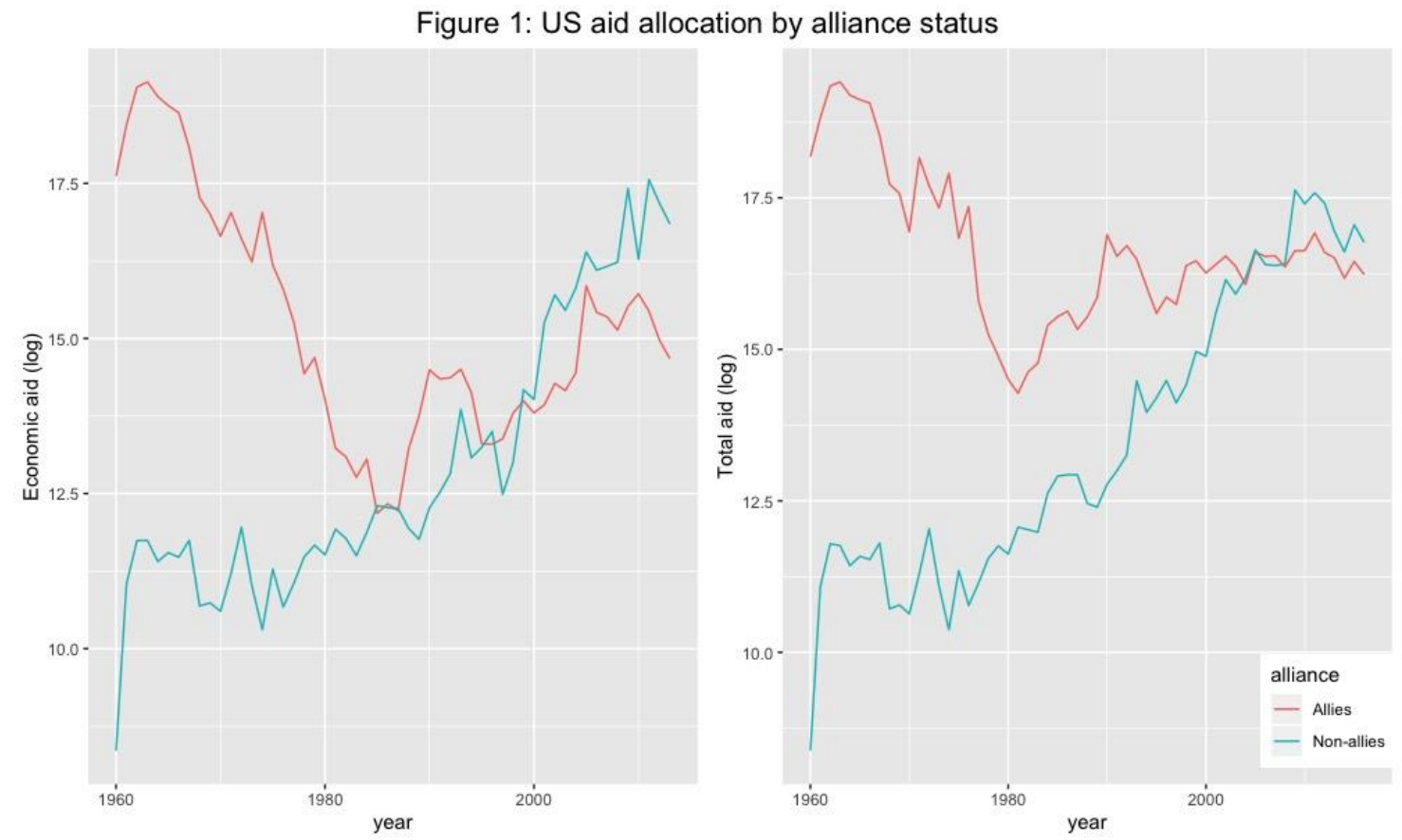

1 Alex Ward. Read Trump's speech to the UN General Assembly. September 25, 2018. Vox. Link: https://www.vox.com/2018/9/25/17901082/trump-un-2018-speech-full-text. Accessed on August 24, 2020. 2 Peter Baker. Trump Says NATO Allies Don't Pay Their Share. Is that True? May 26, 2017. The New York Times. Link: https://www.nytimes.com/2017/05/26/world/europe/nato-trump-spending.html. Accessed on August 25, 2020. 
Please do not circulate or cite without permission of the author.

Figure 2: Aid allocation of major Western donors

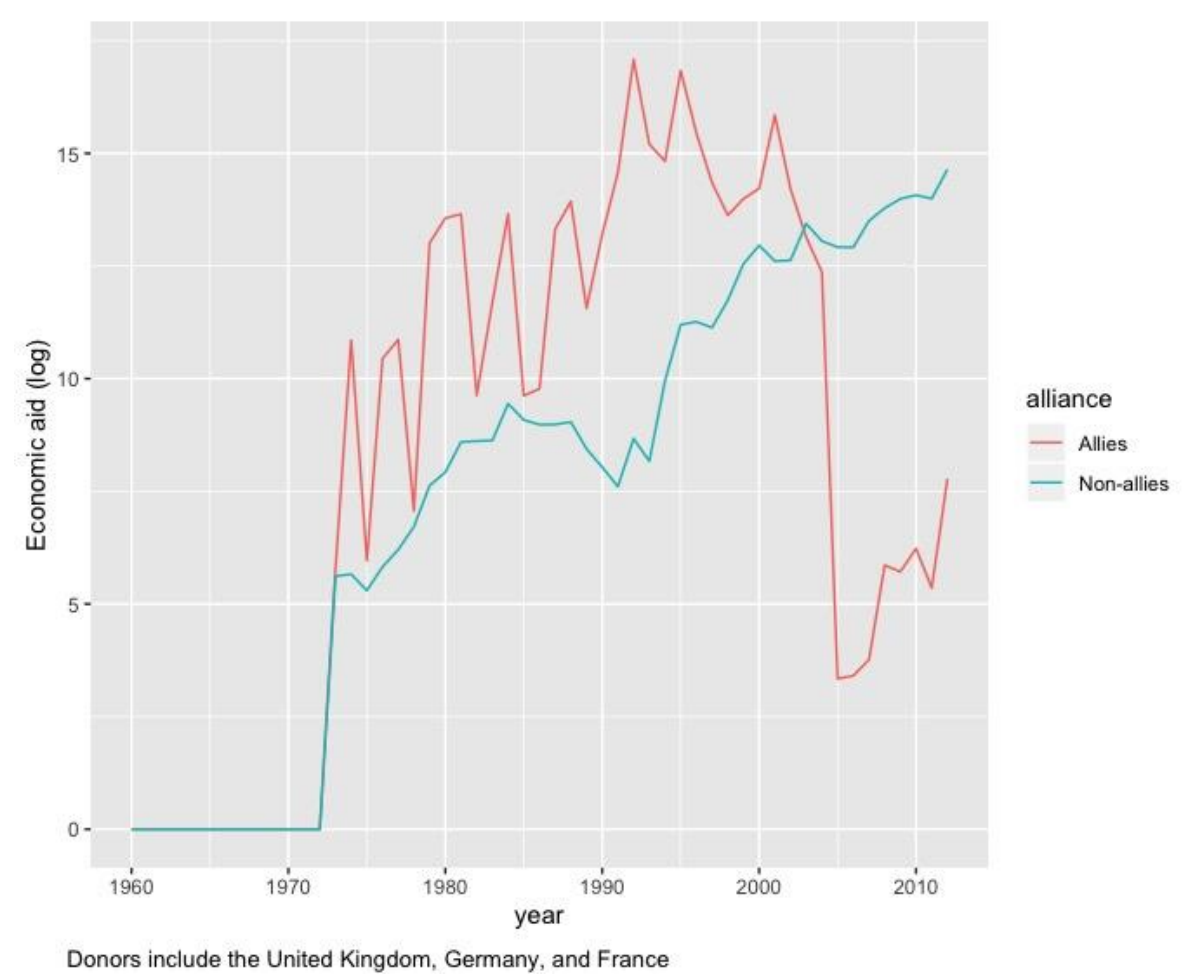

Traditionally, foreign aid scholars believe donors' close friends receive more foreign aid than other countries. For example, Alesina and Dollar find that "colonial and political alliances are major determinants of foreign aid."(Alesina and Dollar 2000) Bermeo includes two variables related to security cooperation-whether a country receives military aid and whether it receives arms transfer from the donor (Sarah Blodgett Bermeo 2017), and she finds that security ties are substantially and positively correlated with foreign aid allocation. Walt devoted a chapter of his pioneer work-The Origins of Alliances to this topic (S. Walt 1990). Through a careful comparative study of American aid to allies and non-allies and attempted alliance-building during the Cold War, he concludes that alliance can significantly increases foreign aid allocation. Meernik and Krueger's research confirms Walt's finding through a quantitative analysis of American aid allocation from 1977 and 1994 (Meernik, Krueger, and Poe 1998). However, the regression results show that allies receive more aid during the Cold War, but the coefficient on the alliance variable after the Cold War is negative and is not statistically significant. They did not go further to examine this issue because the data only covered foreign aid from 1977 and 1994.

Recently, scholars begin to develop a more nuanced understanding of alliance and foreign aid allocation. Bueno de Mesquita and Smith argue that the relationship between alliance and foreign aid is polynomial (Bruce Bueno de Mesquita 2009). In their opinion, donors do not need to buy policy concessions from close allies, and it is too expensive to purchase concessions from enemies. However, this polynomial model does not account for the changing relationship 
Please do not circulate or cite without permission of the author.

between alliance and aid overtime, and it cannot explain why allies may receive less aid than non-allies. Moreover, Fleck and Kilby look into American aid before and after the War on Terror (Fleck and Kilby 2010). Although they do not test alliance directly, one of their covariateswhether a recipient also receives military aid from the US, arguably, alludes to alliance. Their research shows that, with the War on Terror, the US significantly increased foreign aid to strategic partners, particularly countries that provided support for the US military operations during the War on Terror.

This paper will extend the current literature by introducing an omitted variable: the global security environment. It argues that the global security environment mediates alliance's impact on foreign aid allocation. When the level of hostility and insecurity is high, alliance with a great power is both an asset and a liability to smaller states because they might be involved in a major power competition. Meanwhile, both the great power and its allies are likely to face challenges from rivals. Thus, the leading state of the alliance needs to provide aid to defend the alliance, support friendly regimes, and deter opponents. When the security environment is peaceful, allying with a great power is an attractive option to aid-receiving countries. The chance of them being involved in a great power competition is greatly reduced. Not only can they enjoy the security benefits of having a great power as their ally, but they will also have access to a much larger market and develop close economic ties with the great power. Great powers can then use alliance membership as a leverage to achieve their foreign policy goals, thus saving foreign aid expenditure.

This analysis makes two contributions. First, by highlighting under what conditions we are most likely to see a particular pattern of aid giving, this article theorizes aid policy changes by incorporating a systemic variable. Some articles investigated changes in American aid amid major world events but did not generalize their findings. This paper develops a measure of the global security environment that quantifies the specific changes brought about by salient world events. Secondly, this article bridges the foreign aid study and the international security literature by analyzing the foreign aid allocation of 72 pairs of newly established alliances since 1960 and 70 comprehensive bilateral defense cooperation agreements3. Some scholars have examined the connection between aid and military alliance, but alliance was only included as a control variable or a part of the big theory. Also, because alliance is not their main focus, certain endogeneity issues, such as politics' influence on alliance and the historical and cultural ties between a given dyad, are also omitted. Some articles noticed that alliance might be negatively correlated with foreign aid allocation but did not delve deeper, due to data availability issues. This article will deal with potential endogeneity issues with rigorous statistical tests and develop a nuanced analysis of alliance and aid.

Moreover, adding to the debate on the cost of alliance in the policy world, this article shows that alliance is not merely a liability. When the global security environment is favorable to the international system's leading states, alliances can reduce their foreign aid expenditure and financial burden through attraction and substitution mechanisms. When the security environment

3 The number of alliances is counted as the sum of all formal defensive treaties among dyads of states. Alliance data is from the Alliance Treaty Obligations and Provisions (ATOP) project. Bilateral defense cooperation data is from the Defense Cooperation Agreement dataset of the Correlate of War project. 
Please do not circulate or cite without permission of the author.

becomes more competitive, donors are likely to provide more foreign aid but concentrate the resources on existing allies or states with close political ties.

This article proceeds as follows. It will firstly elaborate on the moderating effect on the global security environment and alliance's attraction and substitution mechanisms. Then, it will discuss the operationalization of the global security environment and the statistical model. We will test the hypothesis using foreign aid data of major donors from 1960 to 2013. There will also be multiple robustness checks. It will conclude with a summary and a discussion of this paper's policy implications. 
Please do not circulate or cite without permission of the author.

\section{GLOBAL SECURITY ENVIRONMENT AS A MODERATOR}

The global security environment moderates the relationship between alliance and foreign aid allocation. The global security environment (hereafter referred as GSE) is defined as the sum of revealed hostility and insecurity between all states or groups of states in the international system. This concept is related to the notion of anarchy as Wendt understands it (Wendt 1992). It resembles the continuum of security systems that, in Wendt's term, can range from more competitive security systems to more cooperative security systems. In the same vein, it echoes Jervis and other scholars' conceptualization of "security dilemma", a situation in which states are uncertain about each other's intentions and resort to power accumulation to defend themselves (Herz 1950; Jervis 1978, 2001; Glaser 1997; Tang 2009). A shared understanding of these concepts is that the severity of the security dilemma or anarchy can vary even if the distribution of power does not change. GSE does not assume the nature of states, be they offensive or defensive. It does not presume the source of hostility and insecurity, which can come from humans' aspiration for power, the lack of supranational government, major power competition, ideological divide, historical antagonism, or idiosyncratic factors. GSE emphasizes revealed hostility and insecurity as a result of various forces but does not reckon the cause of it. By focusing on the result, GSE provides a way to skip theoretical divides and synthesize the forces that shape the international system.

GSE is a measure of the extent to which a state views the international system as a competitive one and to what extent other states are a threat to its security. It only accounts for revealed hostility for two reasons. Firstly, as in the economic literature that looks at "revealed preference" rather than actual consumer preferences (Samuelson 1948; Houthakker 1950), we cannot observe and measure latent hostility. Secondly, it is doubtful to what extent latent hostility and insecurity affect foreign policies. The international environment shapes state behaviors through decision-makers' perceptions (Jervis 2017). If a preference is not revealed in behavior, it is unlikely that decision-makers can recognize and respond to it. Lastly, it is essential to note the difference between latent and hidden hostility. If a state secretly builds up its military forces, that is not latent hostility. The hostility is latent as long as it only exists in decisionmakers' minds and is not reflected in behavior.

\section{The moderating effect of global security environment}

A moderator "affects the direction and/or strength of the relation between an independent or predictor variable and a dependent or criterion variable"(Baron and Kenny 1986). GSE alters alliance's impact on foreign aid allocation by affecting alliance's utility. (see the flowchart on page 3) When the level of hostility and insecurity is high, in other words, when states, especially great powers, are armed up and spending a large portion of their revenue on defense, alliance is both an asset and a liability to the smaller allies of a major power. On the one hand, the alliance promises military assistance to the allies of the major power. On the other hand, allies might be involved in major power competition. Under this scenario, as argued by many scholars, aid is more effective as a means to strengthen existing alliances rather than a political instrument to alter third parties or rival states' behaviors (Walt 1990, 224-225). Moreover, when the security environment is competitive, small states are in greater need of external assistance than when the security environment is peaceful. Thus, great power donors need to provide more foreign aid to 
Please do not circulate or cite without permission of the author.

strengthen the alliance and support the allied regime. This principle largely explains the aid policies of the United States and other Western donors during the Cold War. These donors consistently provided foreign aid to friends, allies, and rivals of their enemies (Meernik, Krueger, and Poe 1998; Alesina and Dollar 2000; Clarke, Lee, and Li 2004; Fleck and Kilby 2010; Rudloff, Scott, and Blew 2013).

When the security environment is favorable to the leading states of an alliance, alliance will be a valuable asset to smaller states. The leading states could use alliance as a leverage to achieve their foreign policy goals, thus reducing foreign aid expenditure. The logics are as follows: Firstly, when the security environment is favorable to a great power, alliance with the major power protects smaller allies from external threats; meanwhile, the chance that small allies are involved in major power competition is low. Secondly, when the security environment is favorable, states are more likely to focus on economic development, and allying with the leading states of the international system grants smaller states access to a large market. For example, Central and Eastern European states could get unbridled access to the large European market after joining the North Atlantic Treaty Organization and subsequently, the European Union.

Lastly, the leading states of an alliance are more likely to adopt expansionary strategic goals when the security environment is favorable. For example, in the 1990s, the Clinton administration's strategic goal was to spread market economies and democratic governments (Art 1991; G. J. Ikenberry 2011; Mastanduno 1997; S. M. Walt 2018), and in the 2000s, the Bush administration's goal was to maintain America's political and military predominance (J. G. Ikenberry 2001; Dueck 2004). Both alliance and foreign aid can help donors achieve these goals. Alliance reduces aid allocation through two mechanisms: attraction and substitution. After the Cold War, states in Central and Eastern Europe aspired to join the Transatlantic community, the Clinton and Bush administration could use NATO membership to incentivize Eastern and Central European states to conduct market reforms and democratic transition (attraction effect, see Brinkley 1997; Waterman, Zagorcheva, and Reiter 2002; Epstein 2005). During the War on Terror, bounded by alliance obligations, allies in Eastern and Central Europe also provided critical support for the US's military operations, such as contributing troops and granting the US access to their military bases. These mechanisms substitute the need of using foreign aid to purchase cooperation (see the flowchart at the end of the section).

\section{Attraction mechanism}

Alliance is attractive to smaller powers when the level of hostility and insecurity is low in the system. Allying with a major power amid power rivalries is, however, risky and costly, because it is unlikely for a state to join one side without irritating others. For example, joining the Soviet camp meant that the newborn People's Republic of China chose the US as a competitor. During the Soviet-China split, aligning with the Soviet Union exposed Vietnam to Chinese animosity, which eventually led to the Sino-Vietnam war. In the same vein, siding with Iran during the Iran-Iraq war was Syria's political declaration of war against Iraq. However, allying with a major power when security competition is moderate is a guarantee of security and assistance. Major powers could use alliance membership as an incentive to achieve policy goals and thus reduce the need for foreign aid. This is the attraction mechanism of alliance. For 
Please do not circulate or cite without permission of the author.

example, the Clinton administration explicitly used NATO membership as a carrot to encourage East European states to conduct economic and political liberalization (Lake 1993). Even though there was internal disagreement within the United States, different branches of the government agreed that NATO membership could help the US achieve its foreign policy goals in Eastern Europe. In fact, this was one reason why they designed the Partnership for Peace program. Although the military initially disagreed with President Clinton's fast path of enlargement, they were willing to accept new members if the latter conducted necessary reforms and became ready to contribute before joining the alliance (Goldgeier 1999, 24). Empirical research finds that NATO enlargement indeed contributed to Central and East Europe's economic and democratic transition (Brinkley 1997; Epstein 2005). Meanwhile, Eastern and Central European countries also actively participated in the US- and EU-led military and peacekeeping operations in the Baltics and the Middle East before joining NATO. The Czech Republic contributed 850 combat soldiers to the NATO-led Implementation Force in Bosnia and Herzegovina, and Poland contributed 670.4 Again in 1996, they each contributed about 1,000 soldiers to the UNPROFOR peacekeeping mission5, while other aspiring members, including Hungary Slovakia, Estonia, and Latvia, also contributed. What was more surprising was Ukraine's contribution. It sent 1,084 soldiers to the UNPROFOR mission, and later during the War on Terror, it sent 1,657 soldiers to Iraq. Although it is not a NATO member yet, it has already made it clear its aspiration.6

\section{Substitution mechanism}

The substitution mechanism differs from the attraction mechanism in when they are at work. Alliance involves commitments and obligations, and that can substitute the need for side payment. Once join the alliance, allies are obligated to help the leading states if needed. Even when the global security environment is less competitive, there can be many conflicts. For instance, Nuno observes that even a unipolar world can have many conflicts between the major power and recalcitrant minor powers (Monteiro 2012). When facing with military or political conflicts, secondary allies are expected to join the leading state's sanctions or coercive coalition against rogue states, vote together with the leading states on important international issues, and provide assistance to the leading states' military operations. Donors often need to provide side payment such as foreign aid to elicit support from non-allies, while for allies it is part of the alliance deal. Fleck and Kilby finds that the War on Terror substantially increased American aid to Pakistan, Jordan, and Afghanistan, countries that provided critical support for the US's military operations (Fleck and Kilby 2010). In comparison, formal allies of the US only experienced a modest increase. Other empirical research shows that, all else being equal, allies are more likely to join sanctions and military operations led by the US (Tago 2006; Pilster 2011; Vucetic 2011). Moreover, scholars also find that alliance contributes to successful democratic transitions (Gheciu 2005; D. M. Gibler and Wolford 2006). Donors do not need to intentionally cut foreign assistance to allies. The attraction and substitution mechanisms save donors' financial burdens by reducing the demand of allies.

4 Jan Daniel. Peacekeeping Contributor Profile: Czech Republic. Providing for Peacekeeping. March 2016. Link: http://www.providingforpeacekeeping.org/2016/03/03/peacekeeping-contributor-profile-czech-republicl. Accessed on August 25, 2020.

5 Rafal Tarnogorski. Peacekeeping Contributor Profile: Poland. Providing for Peacekeeping. October 2012. Link: http://www.providingforpeacekeeping.org/2014/04/03/contributor-profile-poland/. Accessed on August 25, 2020. 6 See the NATO page for its relations with Ukraine: Relations with Ukraine. June 12, 2020. NATO. Link: https://www.nato.int/cps/en/natolive/topics_37750.htm. Accessed on July 25, 2020. 
Please do not circulate or cite without permission of the author.

\section{Hypothesis:}

Based on these mechanisms, I hypothesize that

H1: The association between alliance and foreign aid allocation is dependent on the global security environment. Alliance reduces foreign aid when the security environment is benign. When the security environment deteriorates, the negative correlation will gradually turn positive.

\section{A granular theory of alliance formation and foreign aid allocation}

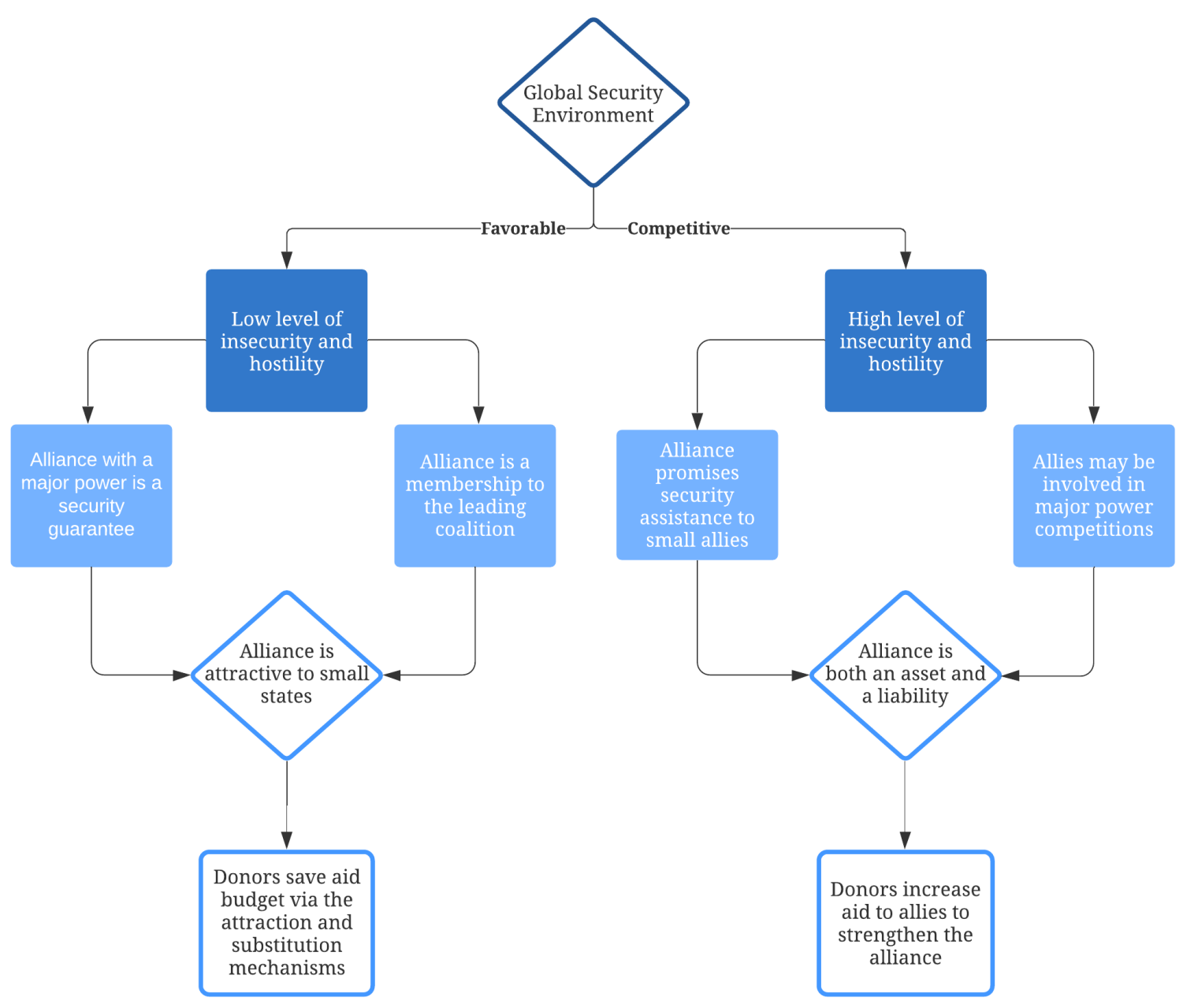


Please do not circulate or cite without permission of the author.

\section{RESEARCH DESIGN}

The analysis tests the hypothesis that alliance's effect on foreign aid allocation is conditional on the global security environment. I explain aid policy variations of four major donors and the universe of recipient countries that are eligible for ODA aid for the period of 1960 to 2013.

The primary outcome of interest is ODA aid. This is the major form of aid of OECD donors. The US also provides large amounts of military aid and economic aid that does not qualify as development assistance. This article will include a robustness check using overall US aid data as the dependent variable. ODA aid data comes from the AidData's Core Research Release 3.1(Tierney et al. 2011). AidData records development finance between 1947 and 2013, and it includes ODA, OOF flows, equity investments, and export credits. I use whether a recipient is still receiving ODA aid from the World Bank as an indicator of its development status and excludes countries that no longer qualify for development assistance. Scholars use aid per capita or aid divided by GDP when examining the economic and political impact of aid and using total amount when studying what affects aid allocation. Since this analysis studies alliance's impact on foreign aid allocation, I use the natural log of aid commitments (constant USD) from a donor to a recipient as the dependent variable.7 I will take the three-year average to remove temporal fluctuation on aid allocation. I only include four donors, the United States, the United Kingdom, France, and Germany because 1) they are the top donors, which account for the vast majority of all foreign aid8 (see the graph below); 2) these countries are first-tier powers around the globe.

7 See, for example, Bermeo 2017, and Bearce and Tirone 2010.

${ }_{8}$ Japan is also a top donor, but it does not have any formal defense treaties with recipients. 
Please do not circulate or cite without permission of the author.

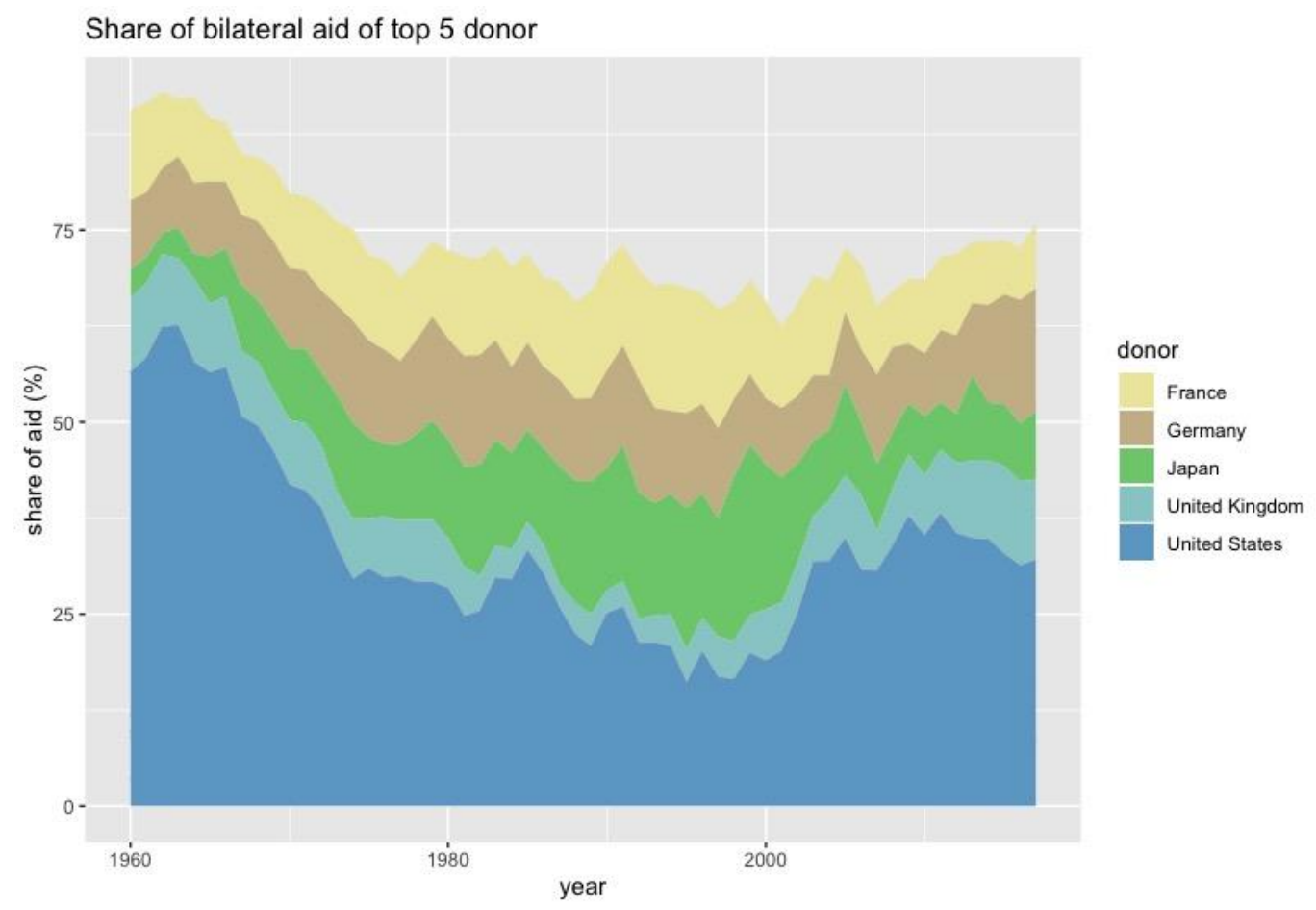

The independent variable is the formal treaty alliance between the donor and a given recipient at year $\mathrm{t}$. The most updated data is available through the Alliance Treaty Obligations and Provisions project (ATOP), which documents military alliance agreements signed by relevant parties between 1815 and 2016.9 It is coded as a dummy variable that varies across country dyad and year. This analysis does not include offense, nonaggression, neutral and consultation pacts because offense and neutral treaties are rare after the Second World War, and nonaggression and consultation pacts largely overlap with formal defense treaties. In total, there are 72 pairs of newly established alliances since 1960 and 118 pairs of alliances in total. (see Table 1 in the appendix for more details) Additionally, I will use comprehensive defense cooperation agreements as an alternative measure of alliance. The data set is compiled by Brandon Kinne (Kinne 2020). I will use general DCAs - agreements that "attempt to coordinate and institutionalize the entirety of their signatories' current and prospective defense relations" as an indicator of alliance. 10 There are 70 DCAs between the four donors and recipients between 1980 and 201011. DCAs focus on security cooperation on substantive issues between signatories, but they do not provide explicit promises of mutual assistance. Therefore, I expect DCAs' attraction and substitution effects to be weaker than that of defense pacts.

\section{Operationalize GSE}

9 Ashley Leeds, B., \& Anac, S. (2005). Alliance institutionalization and alliance performance. International Interactions, 31(3), 183-202.

10 Another type is sector DCAs, agreements that specify cooperation in one of the following four areas: weapon procurement, military training and education, research, and security consultation. See Kinne, Brandon J. "The Defense Cooperation Agreement Dataset (DCAD)." Journal of Conflict Resolution 64, no. 4 (2020): $729-755$. 1170 refers to the DCA agreement between donors and recipients. There are many other DCAs between developed countries or were signed when some states graduated from aid-receiving countries. 
Please do not circulate or cite without permission of the author.

Many indicators, such as polarity and power concentration, can reflect the competitiveness of a system. The graph below summarizes the three categories of indicators that other scholars have used to measure the security environment. At the bottom of the pyramid is the raw material power category. Well-known examples include polarity (Waltz 1979) and the concentration of power (Singer, Bremer, and Stuckey 1972). On the top of the pyramid are indicators of conflicts. Some scholars use the number of battle deaths to measure the peacefulness of the international system (Lacina and Gleditsch 2005; Pinker 2011; Fazal 2014). In between are indicators of military power. Scholars tend to use military spending and the number of military personnel to estimate a state's military strength. This article will use a variation of the military strength indicator to estimate GSE, and the reasons are as follows.

Figure 3: Indicators of the competitiveness of a security system

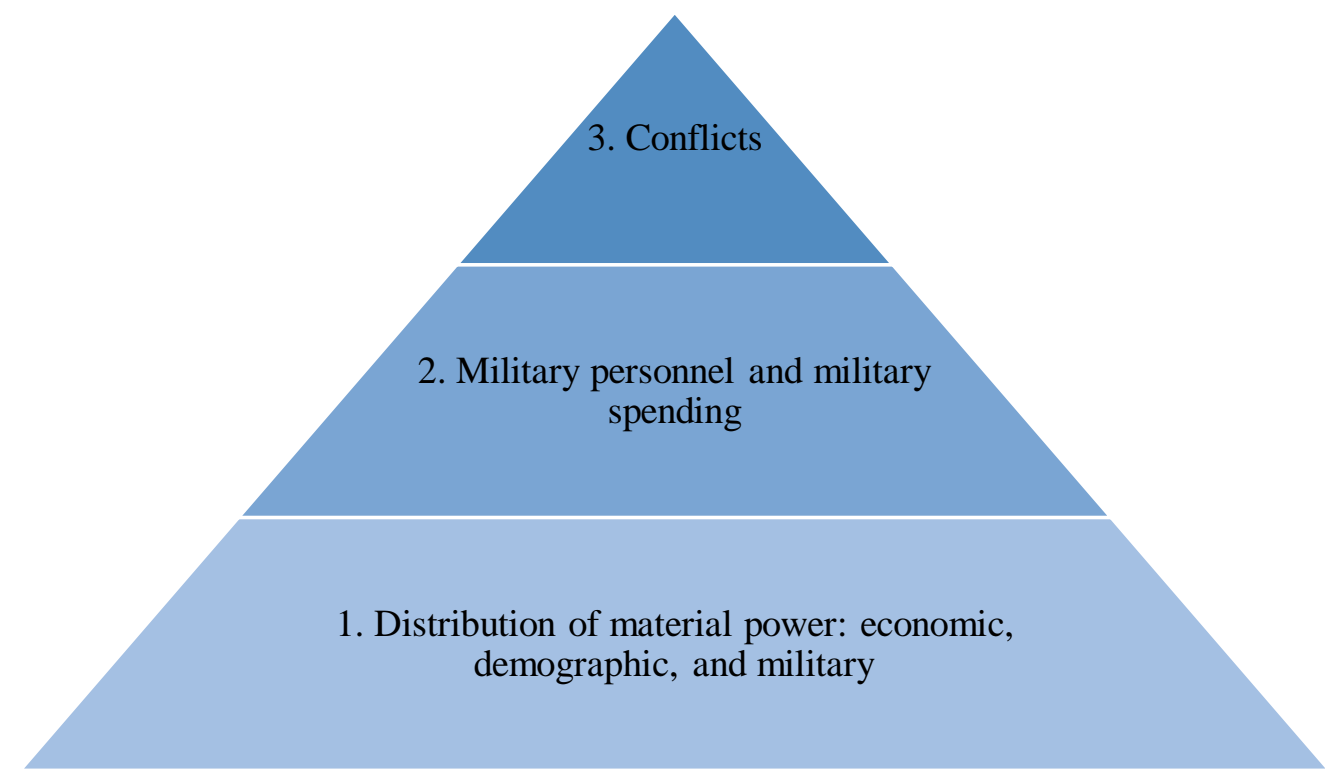

Neither the distribution of material power nor indicators of militarized conflicts directly measure the hostility and insecurity in the international system. When scholars use the distribution of material power to estimate the global security environment, there is an underlying assumption that the distribution of power determines states' behaviors. It is more about the cause of security competition rather than competition per se. Moreover, variants of polarity and power concentration might be able to reflect the long-term trends, but they are unable to capture shortterm changes that lead up to structural transformation. For example, polarity does not tell us the variations of the security environment during the Cold War and under the US hegemony in the 1990s and the 2000s, during which the West's aid policies experienced significant changes. In the same vein, conflicts are the result of hostility and insecurity. It is also important to note that hostility and insecurity do not necessarily result in conflicts. They are only part of the iceberg above the water.

In comparison, military buildup is the state's conscious behavior based on its evaluation of the security environment. Any state that wants to defend itself or to attack another state needs to have a well-equipped military. Unlike other elements of power such as population, territory, and economic output, a state can change its military spending and military size in response to 
Please do not circulate or cite without permission of the author.

internal or external threats. Empirical research also shows that states will increase their military buildup when there are important changes in their respective security environments: when neighboring countries increase their military spending (Albalate, Bel, and Elias 2012; Solarin 2018), when there are regional wars (Maizels and Nissanke 1986; Dunne and Mohammed 1995; Albalate, Bel, and Elias 2012) and major power competition (Maizels and Nissanke 1986; Solarin 2018). To check the measure validity, this analysis will use both the military personnel and military spending indicators to estimate GSE12. Specifically, the operationalization is as follows:

$$
\begin{aligned}
& \text { 1) GSE_spending }{ }_{j t}=\sum_{\mathrm{i} \neq \mathrm{j}}\left(\frac{\text { Mil exp }_{\mathrm{it}} * I}{n_{t} * \log \left(1+\mathrm{D}_{\mathrm{ij}}\right) * \text { World.GDP }}\right) \\
& \text { 2) GSE_personnel } \\
& j t=\sum_{\mathrm{i} \neq \mathrm{j}}\left(\frac{\text { Mil personnel }_{\mathrm{it}} * I}{\mathrm{n}_{\mathrm{t}} * \log \left(1+\mathrm{D}_{\mathrm{ij}}\right)}\right)
\end{aligned}
$$

The first equation is the military expenditure measure, and equation 2 is the military personnel indicator. Milexp $p_{i t}$ is military spending of country I in a given year, and Milpersonnel $_{i t}$ is the number of military personnel of country I in year t. $D_{i j}$ is the geographical distance between country $i$ and donor $j$. This essay deflates military spending and military personnel by geographical distance because the military buildup of a neighboring state may pose a more substantial threat than that of state at a greater distance (Albalate, Bel, and Elias 2012; Solarin 2018). $n_{t}$ is the number of states in the international system in year t. Except for the United States, which has a global outreach, I estimate that the UK, Germany, and France's spheres of interest are confined to a few regions. For example, these donors have shown that they have an interest in the denuclearization of Iran and maintaining peace and stability in the greater Middle East and Northern Africa region, but they do not have an equally keen interest in the denuclearization of North Korea. Thus, this essay calculates the regional security environment for France, Germany, and the United Kingdom by including countries with a radius of 8,000 kilometers. This would cover over half of all countries including Europe, the Middle East, and the majority of Africa and Central Asia.13 "I" is the indicator function denoting whether a state is within the region where the donor has a security interest. $G S E_{j t}$ is the security environment for donor $\mathrm{j}$ in year $\mathrm{t}$.

12 No indicators are perfect. Firstly, military expenditure and personnel indicators are likely to be biased by technological trends. The development of new military technologies could make defense and offense cheaper and reduce the demand for military personnel. Nonetheless, it is unlikely that technologies can drastically change the game. Technologies may affect military's size more than its spending, but the use of both budget and personnel indicators should ameliorate this issue. For example, China has been streamlining the number of its military, but it is increasing its military budget by double-digit percentages. Looking at both indicators could give us more confidence in the evaluation of the security environment. Secondly, the military spending measure might be affected by the form of government. Democracies tend to be more pacific and spend less on the military (Albalate, Bel, and Elias 2012). Since the 1960s, we have witnessed a growth in democratic regimes and a decline of autocracies. Hewitt argues that one of the reasons behind the post-1985 fall in world military spending is the move towards more democratic regimes, alongside the improved world security situation (Hewitt 1993). Thus, it is likely that the low level of military spending since 1990 reflects both a global transition to democracies and a benign security environment. Nonetheless, if democracies are indeed more peaceable, then, the decline in military spending is still a genuine indication of the improvement in the security environment.

13 The threshold is set at 8,000 intentionally to include these regions but exclude East Asia and Latin America. I also test it with a different threshold ranging from 5,000 to 10,000. There is no major change in the results. 
Please do not circulate or cite without permission of the author.

Figure 4 shows how the security environment changes over time for each of the four donors. On the left is the military spending indicator, and on the right is the military personnel indicator. Military personnel and military spending data come from COW's national material capability data set.14 Military personnel only includes the troops under the command of the national government. It uses COW's data on military spending because it has the most time coverage.15 GDP data are available through the World Bank's development indicators database, and geographical distance data comes from the GeoDist project. In the statistical analysis, I will normalize these two variables to have a value between 0 or 1 , so that we can compare the results of models using different indicators of GSE.16

Figure 4: The security environment by donor
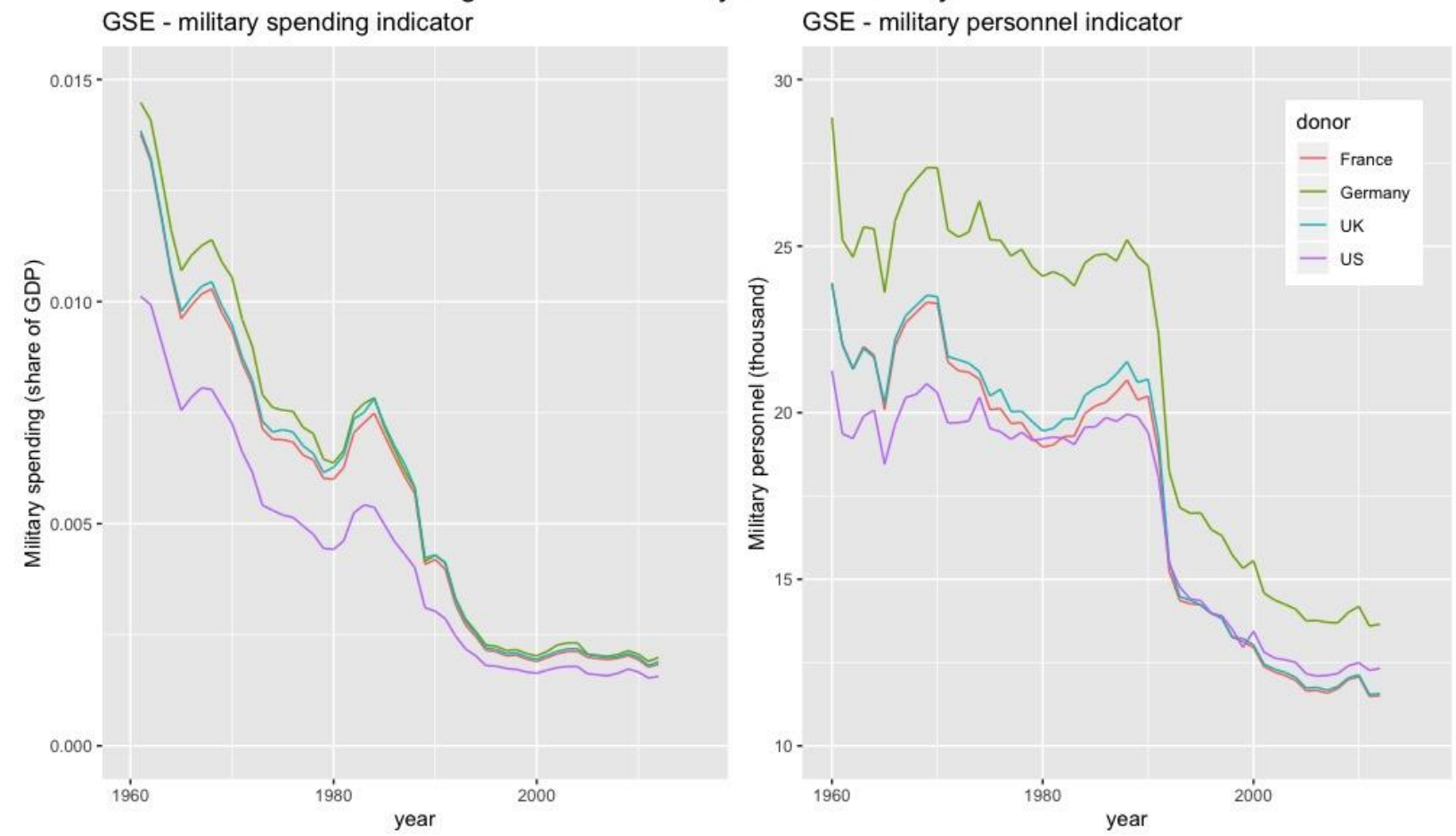

14 Singer, J. David, Stuart Bremer, and John Stuckey. (1972). "Capability Distribution, Uncertainty, and Major Power War, 1820-1965." in Bruce Russett (ed) Peaze, War, and Numbers, Beverly Hills: Sage, 19-48.

15 The Stockholm International Peace Research Institute and Our World in Data also have the data on military spending, but they do not have the data for former Communist regimes until 1988. There is one caveat with COW's military spending data. The numbers on former Communist regimes are not official statistics, and they might have errors due to the difficulties of converting local currencies of former Communist regimes to US donors and separating military budget with civil expenditures.

16 The normalization function is as follows: GSE_normalized ${ }_{j t}=\frac{G S E_{j t}-\min \left(G S E_{j t}\right)}{\max \left(G S \mathrm{E}_{j t}\right)-\min \left(G S E_{j t}\right)}$. $\mathrm{j}$ ” denotes donor $\mathrm{j}$, and $\mathrm{t}$ is year $\mathrm{t}$. 
Please do not circulate or cite without permission of the author.

\section{Control variables}

The main confounders are political factors. Several foreign aid scholars argue that political alignment is the prerequisite for both aid allocation and military cooperation ( $\mathrm{S}$. Walt 1990). The literature on coercion also suggests that the leading state is more likely to recruit states with similar political preferences to join the coercive coalition (D. Gibler and Rider 2004; Pilster 2011; Wolford 2015). Moreover, these authors argue that how close states' political preferences align determines the amount of side payment. Therefore, political preference is a potential confounder. Another potential confounder is regime type. Some authors argue that democracies are better allies and are more likely to join Western-led military coalitions (Pilster 2011; Vucetic 2011; Choi 2012). Foreign aid literature finds that democracies and countries that are conducting democratic transitions generally receive more aid than other recipients (Alesina and Dollar 2000; Fleck and Kilby 2010; Hoeffler and Outram 2011; Sarah Blodgett Bermeo 2017). To control for this potential endogeneity, I include two variables-UN voting distance 17 and polity 2 score from the polity IV project 18 . The first variable capture how close two states' preferences align, and the polity 2 score can measure recipients' regime characters.

Additionally, I include variables measuring state size and bilateral economic relations. Walt believes aggregate state power affects alliance behavior, although he is uncertain about the direction of correlation (Walt 1990, 22-23) States with large aggregate power may trigger alliances against it, but they can also be preferred allies. The coercive diplomacy literature argues that, when building a coalition, the leading states are more willing to recruit bigger powers than smaller ones (D. Gibler and Rider 2004; Wolford 2015). Meanwhile, state power also affects foreign aid allocation. For example, states with higher GDP per capita receive less aid than those that are at the bottom of development (Alesina and Dollar 2000; David Dollar, Victoria Levin 2006; Heinrich 2013; Sarah Blodgett Bermeo 2017). I include two variables to measure state power: population and GDP per capita, all available through the World Bank. I also include annual bilateral export and import as control variables, for that close economic ties may affect alliance behavior and foreign aid allocation. The next control variable is EU membership. Many European states joined the EU soon after their accession to NATO. These two events are likely connected. EU membership is coded as 1 when a new member joins the EU and 0 if otherwise.

\section{Model Specification}

I will analysis each donor individually. The equation below is a mathematical representation of the main model. $Y_{i t+1}$ is the dependent variable-foreign aid from a donor to recipient $i$ in year $t$. Because this article will have separate models for each donor, so " $i$ " represent both a recipient and a specific donor-recipient dyad. $D_{i t-1}$ denotes the alliance status between the recipient and donor at time t. $S_{t}$ is the global security environment. It is a variable at the system level and varies only across time. The interaction term models the moderating effect of global security environment. The model also includes unit (dyad) fixed effect $\left(a_{i}\right)$ to control for time-invariant confounders and time fixed effect $\left(c_{t}\right)$ to control for time trend and

17 Bailey, Michael A., Anton Strezhnev, and Erik Voeten. 2017. Estimating dynamic state preferences from united nations voting data. Journal of Conflict Resolution 61 (2): 430-56.

18 Polity, I. V. "Polity IV Project: Political Regime Characteristics and Transitions, 1800-2014." On-line (http://www. systemicpeace. org/polity/polity4. htm) (2015) 
Please do not circulate or cite without permission of the author.

confounders correlated with time. $Y_{i t}$ is the dependent lagged by 3 years to control for feedback effect.

$$
Y_{i t+1}=\beta_{0}+\gamma_{0} D_{i t}+\beta_{S} S_{t}+\gamma_{1} D_{i t} S_{t}+Y_{i t}+a_{i}+c_{t}+\epsilon_{i t}
$$

The fixed-effects model relies on two critical assumptions: that 1) past treatment does not directly affect current outcome (no carryover effect), and 2) past outcome does not directly affect the current treatment (no feedback effect)(Imai and Kim 2016). Theoretically, these two assumptions hold in this research. Firstly, unlike certain economic and social policies, whose impacts are slow to emerge and last for a long time after implementation, leaders respond to external political changes and adjust their aid policies quickly. This analysis uses aid commitment rather than aid disbursement in the dependent variable. As scholars pointed out, aid allocation may lag the initial decision by several years (Sarah Blodgett Bermeo 2017), but this is less an issue for aid commitment. The feedback effect is essentially one of reverse causality. Does alliance affect foreign aid, or does aid lead to alignment, enabling wealthy states to attract reliable allies by offering generous financial assistance? Existing research believes that the former is true. In Walt's analysis of major world events between 1955 and 1979, he finds that foreign assistance is usually provided in response to a particular external challenge, and in his opinion, foreign aid is the manifestation of alliance rather than the cause of it (S. Walt 1990). In the same vein, other scholars find aid to be either the result of, or a response to, major political events, rather than their causes. Alesina and Dollar's analysis of the connection between democratization and foreign aid is one example (Alesina and Dollar 2000). Typically, large amounts of economic aid are provided as a reward to democratization. Donors may use aid to promote gradual improvement in governance and economic liberalization, but aid, by itself, is unlikely to be the cause of major political and security events such as alliance and regime change. Nonetheless, to control for these two issues, I will lag the independent and moderate variables and include lagged DV on the right side of the equation.19 If aid indeed causes alliance, the inclusion of the lagged DV and the lag of IV should be to capture this mechanism.

Lastly, it is likely that donors provide large amounts of aid when negotiating the alliance terms with a recipient and slightly reduce the amount when they establish the alliance. For instance, The US Congress adopted the NATO Participation Act in 1995 and the NATO Enlargement Facilitation Act in 1995. Both legislations contained clauses of providing foreign aid to prospective allies. In this case, even if we observe a decline in aid when an alliance is established, it is likely that new allies still receive more aid than the pre-negotiation period. This analysis will include a negotiation variable that codes the five years before signing the defense treaty as a control variable.20 Moreover, this variable might be able to capture the attraction effect. If donors could use alliance membership as a leverage to solicit policy concessions from aspiring members, we are expected to see aid starting to decline even before establishing the alliance. However, it will be hard to tell of both of the above logics are at work.

19 Specifically, I will use the IV and moderator variable in year t-1, and the DV will be the average amount of aid from year $\mathrm{t}$ to $\mathrm{t}+2$.

20 I only include this control variables for models using formal defensive treaties as the IV but for models using DCAs to measure alliance. This is because DCAs are more flexible and they are often signed as supplement agreements between formal allies. They do not require a long period of negotiation as formal defensive treaties. 
Please do not circulate or cite without permission of the author.

\section{RESULTS}

This article hypothesizes that the global security environment mediates the relationship between alliance and foreign aid. Alliance is negative correlated with foreign aid when the security environment is favorable, and it will be positively correlated with aid when the security environment is competitive. Therefore, we are expected to see the coefficients on the interaction term to be positive and the coefficients on alliance to be negative. Table 2 presents the results of models using formal defense pacts as the independent variable, and Table 3 presents the results with DCAs as the IV. All models employ dyad and year fixed effects and include the lagged DV on the right side of the equation. In each table, Model 1 to Model 4 use the military personnel indicator of GSE, and Model 5 and Model 8 use the military spending indicator of GSE. From Model 1 to 4 (and from 5 to 8) are analyses of US, UK, France, and Germany respectively.

The results are consistent with the hypothesis. They show that when an aid-receiving country joins an alliance with a major power, it is very likely to experience an aid cut. In Table 2 , coefficients on the alliance variable are negative and statistically significant, and coefficients on the interaction term are also as expected except for models on Germany. In Table 3, where we use DCAs as the independent variable, coefficients on alliance are not statistically differentiable from 0 . As discussed in the previous section, this can be explained by the difference between formal defense pacts and DCAs. A formal defense treaty provides a guarantee of mutual assistance. It is a valuable asset to small countries. In comparison, DCAs establish institutionalized military cooperation between donors and recipients but do not provide explicit guarantees of mutual assistance. Therefore, their attraction and substitution effects are not as strong as those of defense pacts. Also, coefficients on the interaction term are positive and statistically significant except for the two Germany models. In combination, table 3 shows that donors do not provide allies more aid than to non-allies, but they will increase assistance to allies when the security environment becomes more competitive.

The results also show that the most powerful donor is more likely to reduce aid to new allies than other donors. The coefficient on the interaction term in Model 1 of Table 2 is not statistically differentiable from 0. It shows that the US may not increase aid to allies even if GSE deteriorates. As the most powerful country since the end of the Second World War, the US could provide more public goods (security) to allies than other donors. Thus, states would be more willing to ally with the US than with other donors that the US does not need to provide additional foreign aid. Mover, coefficients on the interaction term of other donors (in Table 2 and 3) are larger than those in the US models. They show that when the security environment is competitive, other donors are more likely to increase aid to allies than the United States. 
Please do not circulate or cite without permission of the author.

Table 2: Main Results

\begin{tabular}{|c|c|c|c|c|c|c|c|c|}
\hline & \multicolumn{8}{|c|}{ Dependent variable:ODA aid } \\
\hline & \multicolumn{4}{|c|}{ Military personnel measure of GSE } & \multicolumn{4}{|c|}{ Military spending measure of GSE } \\
\hline & United States & United Kingdom & France & Germany & United States & United Kingdom & France & Germany \\
\hline Alliance & $\begin{array}{c}-4.705^{* * *} \\
(1.188)\end{array}$ & $\begin{array}{c}-7.424^{* * *} \\
(1.182)\end{array}$ & $\begin{array}{c}-5.156^{* * *} \\
(1.282)\end{array}$ & $\begin{array}{c}-4.227^{* * *} \\
(1.198)\end{array}$ & $\begin{array}{c}-6.366^{* * *} \\
(1.760)\end{array}$ & $\begin{array}{c}-7.235^{* * *} \\
(1.268)\end{array}$ & $\begin{array}{c}-6.456^{* * *} \\
(1.506)\end{array}$ & $\begin{array}{l}-2.857 \\
(1.851)\end{array}$ \\
\hline Alliance * GSE & $\begin{array}{l}1.968^{* *} \\
(0.862)\end{array}$ & $\begin{array}{c}8.276^{* * *} \\
(1.461)\end{array}$ & $\begin{array}{c}6.247^{* * *} \\
(1.071)\end{array}$ & $\begin{array}{c}9.846^{* * *} \\
(2.562)\end{array}$ & $\begin{array}{l}1.701^{*} \\
(0.883)\end{array}$ & $\begin{array}{c}5.623^{* * *} \\
(1.210)\end{array}$ & $\begin{array}{c}5.651^{* * *} \\
(0.713)\end{array}$ & $\begin{array}{c}1.453 \\
(5.985)\end{array}$ \\
\hline Population & $\begin{array}{l}-1.100 \\
(1.217)\end{array}$ & $\begin{array}{l}-1.209 \\
(1.041)\end{array}$ & $\begin{array}{l}-1.242 \\
(1.053)\end{array}$ & $\begin{array}{c}-3.660^{* * *} \\
(1.261)\end{array}$ & $\begin{array}{c}1.908 \\
(1.900)\end{array}$ & $\begin{array}{c}2.569 \\
(1.705)\end{array}$ & $\begin{array}{l}-1.250 \\
(1.609)\end{array}$ & $\begin{array}{l}-2.380 \\
(1.996)\end{array}$ \\
\hline polity2 score & $\begin{array}{c}0.026 \\
(0.027)\end{array}$ & $\begin{array}{c}0.097^{* * *} \\
(0.027)\end{array}$ & $\begin{array}{l}-0.009 \\
(0.032)\end{array}$ & $\begin{array}{l}-0.025 \\
(0.026)\end{array}$ & $\begin{array}{c}0.002 \\
(0.038)\end{array}$ & $\begin{array}{l}0.061^{*} \\
(0.035)\end{array}$ & $\begin{array}{l}-0.022 \\
(0.027)\end{array}$ & $\begin{array}{l}-0.050 \\
(0.033)\end{array}$ \\
\hline GDP per capita & $\begin{array}{l}-0.166 \\
(0.435)\end{array}$ & $\begin{array}{c}-1.066^{* *} \\
(0.434)\end{array}$ & $\begin{array}{l}-0.025 \\
(0.383)\end{array}$ & $\begin{array}{l}-0.430 \\
(0.390)\end{array}$ & $\begin{array}{l}-0.350 \\
(0.485)\end{array}$ & $\begin{array}{l}-0.105 \\
(0.477)\end{array}$ & $\begin{array}{c}0.374 \\
(0.349)\end{array}$ & $\begin{array}{l}-0.342 \\
(0.450)\end{array}$ \\
\hline UNSC member & $\begin{array}{c}0.041 \\
(0.257)\end{array}$ & $\begin{array}{l}-0.244 \\
(0.253)\end{array}$ & $\begin{array}{l}-0.268 \\
(0.196)\end{array}$ & $\begin{array}{l}-0.208 \\
(0.268)\end{array}$ & $\begin{array}{l}-0.207 \\
(0.301)\end{array}$ & $\begin{array}{l}-0.192 \\
(0.314)\end{array}$ & $\begin{array}{l}-0.308 \\
(0.215)\end{array}$ & $\begin{array}{l}-0.364 \\
(0.346)\end{array}$ \\
\hline ODA aid at $\mathrm{t}-1$ & $\begin{array}{c}0.326^{* * *} \\
(0.025)\end{array}$ & $\begin{array}{c}0.236^{* * *} \\
(0.021)\end{array}$ & $\begin{array}{c}0.311^{* * *} \\
(0.023)\end{array}$ & $\begin{array}{c}0.204^{* * *} \\
(0.020)\end{array}$ & $\begin{array}{c}0.312^{* * *} \\
(0.032)\end{array}$ & $\begin{array}{c}0.242^{* * *} \\
(0.021)\end{array}$ & $\begin{array}{c}0.256^{* * *} \\
(0.026)\end{array}$ & $\begin{array}{c}0.176^{* * * *} \\
(0.022)\end{array}$ \\
\hline UN voting & $\begin{array}{c}-1.467^{* * *} \\
(0.279)\end{array}$ & $\begin{array}{l}-0.540 \\
(0.415)\end{array}$ & $\begin{array}{l}-0.515 \\
(0.354)\end{array}$ & $\begin{array}{c}-0.479^{*} \\
(0.276)\end{array}$ & $\begin{array}{c}-0.975^{* *} \\
(0.386)\end{array}$ & $\begin{array}{c}0.442 \\
(0.489)\end{array}$ & $\begin{array}{l}-0.444 \\
(0.333)\end{array}$ & $\begin{array}{c}0.181 \\
(0.406)\end{array}$ \\
\hline EU member & $\begin{array}{c}-5.869^{* * *} \\
(1.048)\end{array}$ & $\begin{array}{c}-1.978^{*} \\
(1.019)\end{array}$ & $\begin{array}{c}-5.198^{* * *} \\
(1.237)\end{array}$ & $\begin{array}{c}-4.133^{* * *} \\
(1.044)\end{array}$ & $\begin{array}{c}-4.087^{* * *} \\
(1.490)\end{array}$ & $\begin{array}{c}-2.349^{*} \\
(1.204)\end{array}$ & $\begin{array}{c}-5.631^{* * *} \\
(1.614)\end{array}$ & $\begin{array}{c}-4.814^{* * *} \\
(1.180)\end{array}$ \\
\hline Negotiation & $\begin{array}{l}-0.501 \\
(0.693)\end{array}$ & $\begin{array}{c}-1.766^{*} \\
(1.009)\end{array}$ & $\begin{array}{l}-0.864 \\
(0.535)\end{array}$ & $\begin{array}{c}1.038 \\
(1.109)\end{array}$ & $\begin{array}{l}-0.615 \\
(0.929)\end{array}$ & $\begin{array}{c}-2.112^{* *} \\
(0.860)\end{array}$ & $\begin{array}{c}-1.555^{* * *} \\
(0.470)\end{array}$ & $\begin{array}{c}1.427 \\
(1.213)\end{array}$ \\
\hline Export to donor & $\begin{array}{c}-0.219^{* *} \\
(0.098)\end{array}$ & $\begin{array}{c}0.049 \\
(0.143)\end{array}$ & $\begin{array}{l}-0.025 \\
(0.123)\end{array}$ & $\begin{array}{l}-0.099 \\
(0.144)\end{array}$ & $\begin{array}{l}-0.161 \\
(0.139)\end{array}$ & $\begin{array}{l}-0.082 \\
(0.146)\end{array}$ & $\begin{array}{l}-0.098 \\
(0.089)\end{array}$ & $\begin{array}{l}-0.147 \\
(0.133)\end{array}$ \\
\hline Import from donor & $\begin{array}{c}0.044 \\
(0.145) \\
\end{array}$ & $\begin{array}{c}0.129 \\
(0.176) \\
\end{array}$ & $\begin{array}{c}0.158 \\
(0.156) \\
\end{array}$ & $\begin{array}{c}0.204 \\
(0.138) \\
\end{array}$ & $\begin{array}{l}-0.030 \\
(0.180) \\
\end{array}$ & $\begin{array}{l}-0.103 \\
(0.175) \\
\end{array}$ & $\begin{array}{l}-0.058 \\
(0.129) \\
\end{array}$ & $\begin{array}{c}0.239 \\
(0.162) \\
\end{array}$ \\
\hline Year FE & yes & yes & yes & yes & yes & yes & yes & yes \\
\hline Unit FE & yes & yes & yes & yes & yes & yes & yes & yes \\
\hline Observations & 5,197 & 5,164 & 5,168 & 5,162 & 3,566 & 3,508 & 3,516 & 3,507 \\
\hline & 0.754 & 0.736 & 0.789 & 0.775 & 0.783 & 0.773 & 0.812 & 0.806 \\
\hline Residual Std. Error & $3.428(\mathrm{df}=4986)$ & $3.501(\mathrm{df}=4953)$ & $3.141(\mathrm{df}=4957)$ & $3.212(\mathrm{df}=4951)$ & $3.112(\mathrm{df}=3369)$ & $3.204(\mathrm{df}=3311)$ & $2.435(\mathrm{df}=3319)$ & $2.938(\mathrm{df}=3311)$ \\
\hline
\end{tabular}


Please do not circulate or cite without permission of the author.

Table 3: Main results: using DCAs to measure alliance

\begin{tabular}{|c|c|c|c|c|c|c|c|c|}
\hline & \multicolumn{8}{|c|}{ Dependent variable:ODA aid } \\
\hline & \multicolumn{4}{|c|}{ Military personnel measure of GSE } & \multicolumn{4}{|c|}{ Military spending measure of GSE } \\
\hline & United States & United Kingdom & France & Germany & United States & United Kingdom & France & Germany \\
\hline Alliance & $\begin{array}{l}-0.535 \\
(0.802)\end{array}$ & $\begin{array}{l}-1.497 \\
(1.134)\end{array}$ & $\begin{array}{l}-0.941 \\
(0.777)\end{array}$ & $\begin{array}{c}0.390 \\
(2.357)\end{array}$ & $\begin{array}{c}0.072 \\
(0.834)\end{array}$ & $\begin{array}{l}-1.820 \\
(1.167)\end{array}$ & $\begin{array}{l}-0.725 \\
(0.622)\end{array}$ & $\begin{array}{c}2.575 \\
(2.332)\end{array}$ \\
\hline Alliance* GSE & $\begin{array}{c}6.954^{* * *} \\
(1.312)\end{array}$ & $\begin{array}{l}7.768^{* *} \\
(3.752)\end{array}$ & $\begin{array}{c}10.343^{* * *} \\
(3.915)\end{array}$ & $\begin{array}{c}-8.268 \\
(10.705)\end{array}$ & $\begin{array}{c}9.115^{* * *} \\
(1.646)\end{array}$ & $\begin{array}{c}18.464^{* *} \\
(7.939)\end{array}$ & $\begin{array}{c}12.050^{* * *} \\
(1.784)\end{array}$ & $\begin{array}{c}-75.370^{*} \\
(39.011)\end{array}$ \\
\hline GDP & $(0.000)$ & $\begin{array}{c}0.746 \\
(1.312)\end{array}$ & $\begin{array}{l}-1.043 \\
(1.365)\end{array}$ & $\begin{array}{c}-3.012^{* *} \\
(1.494)\end{array}$ & $(0.000)$ & $\begin{array}{c}0.791 \\
(1.306)\end{array}$ & $\begin{array}{l}-0.901 \\
(1.377)\end{array}$ & $\begin{array}{c}-2.975^{* *} \\
(1.501)\end{array}$ \\
\hline polity2 score & $\begin{array}{c}0.012 \\
(0.032)\end{array}$ & $\begin{array}{c}0.081^{* * *} \\
(0.028)\end{array}$ & $\begin{array}{l}-0.044 \\
(0.032)\end{array}$ & $\begin{array}{c}-0.053^{* *} \\
(0.027)\end{array}$ & $\begin{array}{c}0.013 \\
(0.032)\end{array}$ & $\begin{array}{c}0.081^{* * *} \\
(0.028)\end{array}$ & $\begin{array}{l}-0.045 \\
(0.032)\end{array}$ & $\begin{array}{c}-0.053^{* *} \\
(0.027)\end{array}$ \\
\hline GDP per capita & $\begin{array}{l}-0.410 \\
(0.408)\end{array}$ & $\begin{array}{l}-1.677 \\
(1.310)\end{array}$ & $\begin{array}{c}1.333 \\
(1.345)\end{array}$ & $\begin{array}{l}2.897^{* *} \\
(1.413)\end{array}$ & $\begin{array}{l}-0.421 \\
(0.409)\end{array}$ & $\begin{array}{l}-1.719 \\
(1.305)\end{array}$ & $\begin{array}{c}1.199 \\
(1.350)\end{array}$ & $\begin{array}{l}2.869^{* *} \\
(1.420)\end{array}$ \\
\hline UNSC & $\begin{array}{l}-0.098 \\
(0.283)\end{array}$ & $\begin{array}{l}-0.378 \\
(0.275)\end{array}$ & $\begin{array}{c}-0.375^{*} \\
(0.226)\end{array}$ & $\begin{array}{l}-0.214 \\
(0.303)\end{array}$ & $\begin{array}{l}-0.097 \\
(0.283)\end{array}$ & $\begin{array}{l}-0.370 \\
(0.274)\end{array}$ & $\begin{array}{c}-0.378^{*} \\
(0.223)\end{array}$ & $\begin{array}{l}-0.224 \\
(0.300)\end{array}$ \\
\hline ODA aid at & $\begin{array}{c}0.323^{* * *} \\
(0.028)\end{array}$ & $\begin{array}{c}0.260^{* * *} \\
(0.023)\end{array}$ & $\begin{array}{c}0.321^{* * *} \\
(0.026)\end{array}$ & $\begin{array}{c}0.180^{* * *} \\
(0.021)\end{array}$ & $\begin{array}{c}0.323^{* * *} \\
(0.028)\end{array}$ & $\begin{array}{c}0.260^{* * *} \\
(0.023)\end{array}$ & $\begin{array}{c}0.323^{* * *} \\
(0.027)\end{array}$ & $\begin{array}{c}0.183^{* * *} \\
(0.021)\end{array}$ \\
\hline UN voting & $\begin{array}{c}-8.674^{* * *} \\
(0.944)\end{array}$ & $\begin{array}{c}-6.025^{* * *} \\
(0.919)\end{array}$ & $\begin{array}{c}-8.655^{* * *} \\
(0.854)\end{array}$ & $\begin{array}{c}-8.073^{* * *} \\
(1.116)\end{array}$ & $\begin{array}{c}-8.646^{* * *} \\
(0.943)\end{array}$ & $\begin{array}{c}-6.171^{* * *} \\
(0.917)\end{array}$ & $\begin{array}{c}-8.848^{* * *} \\
(0.871)\end{array}$ & $\begin{array}{c}-7.967^{* * *} \\
(0.978)\end{array}$ \\
\hline EU member & $\begin{array}{c}-6.474^{* * *} \\
(0.939)\end{array}$ & $\begin{array}{c}-2.309^{* *} \\
(1.030)\end{array}$ & $\begin{array}{c}-5.579^{* * *} \\
(0.927)\end{array}$ & $\begin{array}{c}-3.719^{* * *} \\
(1.277)\end{array}$ & $\begin{array}{c}-5.793^{* * *} \\
(1.053)\end{array}$ & $\begin{array}{c}-3.006^{* * *} \\
(1.033)\end{array}$ & $\begin{array}{c}-6.303^{* * *} \\
(0.946)\end{array}$ & $\begin{array}{c}-4.895^{* * *} \\
(1.178)\end{array}$ \\
\hline Negotiation & $\begin{array}{l}-0.471 \\
(0.651)\end{array}$ & $\begin{array}{c}-1.961^{* *} \\
(0.890)\end{array}$ & $\begin{array}{l}-0.360 \\
(0.383)\end{array}$ & $\begin{array}{c}0.420 \\
(1.068)\end{array}$ & $\begin{array}{r}-0.380 \\
(0.617)\end{array}$ & $\begin{array}{c}-2.065^{* * *} \\
(0.780)\end{array}$ & $\begin{array}{r}-0.478 \\
(0.344)\end{array}$ & $\begin{array}{c}0.248 \\
(1.091)\end{array}$ \\
\hline Export to donor & $\begin{array}{l}-0.152 \\
(0.118)\end{array}$ & $\begin{array}{c}0.013 \\
(0.161)\end{array}$ & $\begin{array}{c}-0.068 \\
(0.115)\end{array}$ & $\begin{array}{l}-0.127 \\
(0.159)\end{array}$ & $\begin{array}{c}-0.154 \\
(0.118)\end{array}$ & $\begin{array}{c}0.012 \\
(0.161)\end{array}$ & $\begin{array}{l}-0.071 \\
(0.115)\end{array}$ & $\begin{array}{c}-0.128 \\
(0.158)\end{array}$ \\
\hline Import from donor & $\begin{array}{l}-0.171 \\
(0.169) \\
\end{array}$ & $\begin{array}{c}0.019 \\
(0.203) \\
\end{array}$ & $\begin{array}{c}-0.018 \\
(0.155)\end{array}$ & $\begin{array}{l}0.313^{* *} \\
(0.148)\end{array}$ & $\begin{array}{c}-0.170 \\
(0.169)\end{array}$ & $\begin{array}{c}0.016 \\
(0.203)\end{array}$ & $\begin{array}{r}-0.028 \\
(0.155)\end{array}$ & $\begin{array}{c}0.308^{* *} \\
(0.148)\end{array}$ \\
\hline Year FE & yes & yes & yes & yes & yes & yes & yes & yes \\
\hline Unit FE & yes & yes & yes & yes & yes & yes & yes & yes \\
\hline Observations & 4,332 & 4,332 & 4,332 & 4,332 & 4,332 & 4,332 & 4,332 & 4,332 \\
\hline $\mathrm{R}^{2}$ & 0.762 & 0.750 & 0.788 & 0.798 & 0.762 & 0.750 & 0.787 & 0.798 \\
\hline Residual Std. Error $(\mathrm{df}=4131)$ & 3.260 & 3.443 & 2.996 & 3.051 & 3.262 & 3.443 & 2.999 & 3.047 \\
\hline
\end{tabular}


Please do not circulate or cite without permission of the author.

The marginal effect of alliance
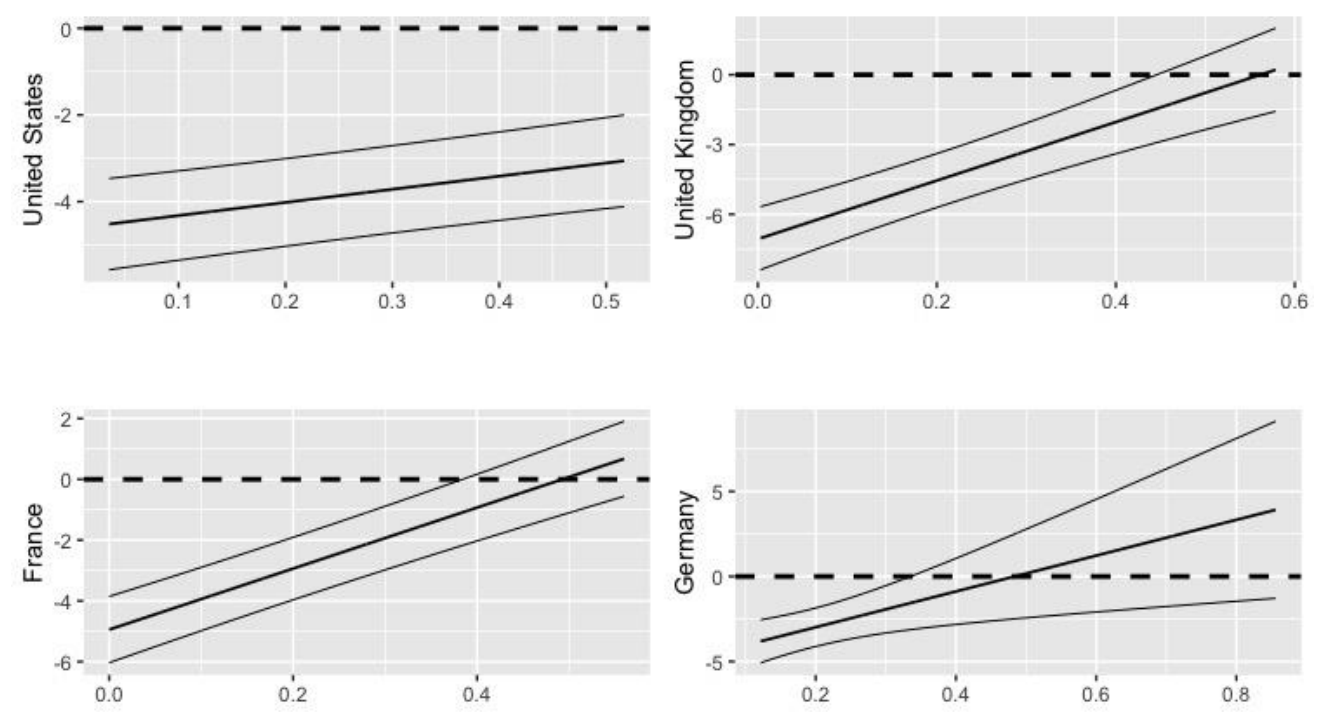

Global security environment

Note: the graph is produced based on Table 2.

\section{Military and non-ODA aid}

Lastly, I have only examined official development assistance. Donors will likely compensate small allies through non-ODA aid or military aid. I will examine this possibility using the Greenbook aid data of the United States.21 The data is collected by US Agency for International Development and is open to the public. It records two types of foreign assistance, economic aid (ODA and non-ODA aid), and military aid. I only analyze the US because that is the only data available. As the graph below demonstrates, unlike economic aid, American allies still receive more military aid than non-allies. Thus, I expect the allocation of economic aid and total aid is consistent with the theory, while military aid is less likely to follow this pattern.

21 USAID. "US overseas loans and grants." (2014). 
Please do not circulate or cite without permission of the author.

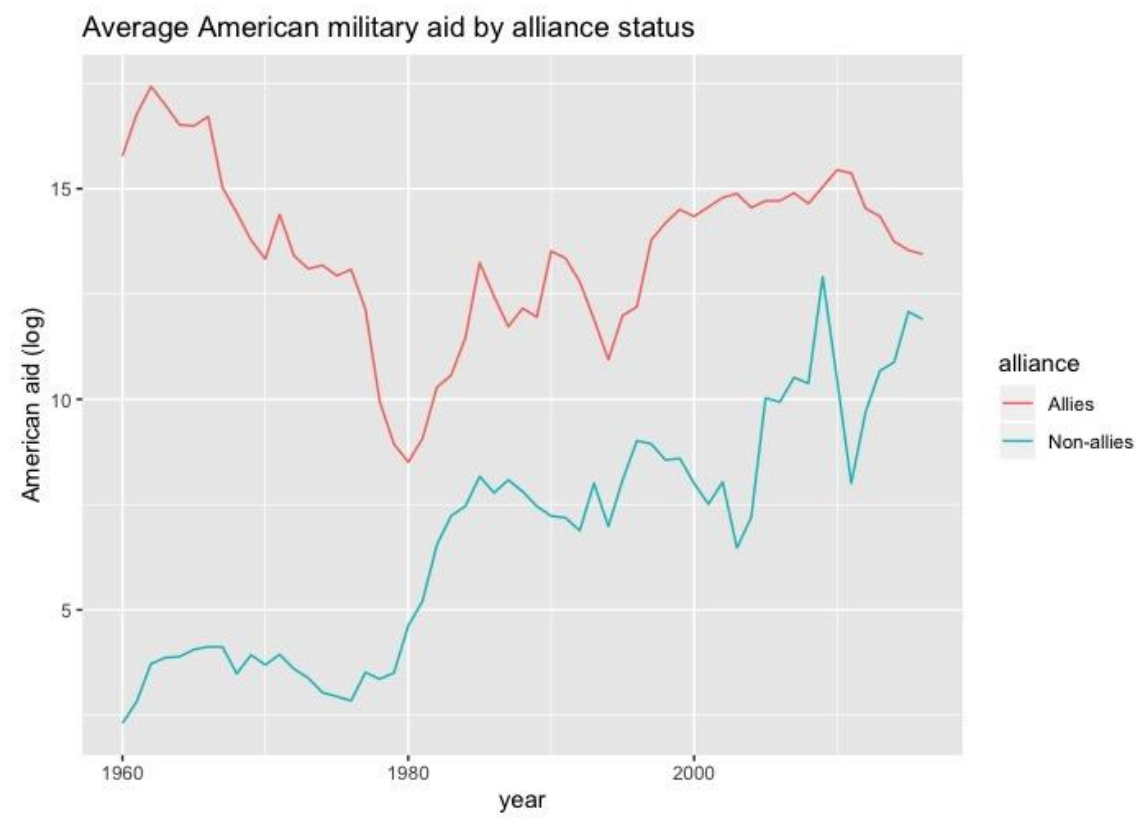

Table 4 presents the results. Model 1 to model 3 use the military personnel indicator of GSE, and model 4 to model 6 use the military spending indicator. For models of economic and total aid, coefficients on the independent variable and the interaction term all have the correct signs and are mostly statistically significant at $a=0.10$ or 0.05 . Compared to the results in Table 2 , the US is likely to have compensated donors with non-ODA aid. Nonetheless, the results are still consistent with the hypothesis. Coefficients on the interaction term in Model 3 and Model 6, which analyze total aid, are positive and statistically significant at $a=0.05$ or 0.01 . When the global security environment is friendly, allying with the US will result in a decline in overall aid. However, as the environment becomes more competitive, the US will increase its aid to allies (The marginal graph below shows alliance's marginal effect on foreign aid allocation).

Military aid allocation does not seem to be affected by either alliance status or to vary as the global security environment changes. (see the figure below) This is not to say that alliance is not strategically important. Military aid is likely driven by the US's military operations and security considerations, which can involve both allies and non-allies. During the Cold War, the US provided substantial military aid to not only allies but also non-allies that were at the forefront of the East-West confrontation (Poe and Meernik 1995). During the War on Terror, Pakistan was among the top recipients of US military assistance and arms transfer, although not long-ago Pakistan was still sanctioned, and foreign aid was prohibited.22 Compared to economic aid, it is likely that actual needs rather than political considerations drive military aid.

The results of the negotiation variable in Table 2 and Table 4 are interesting. Coefficients of this variable all have negative signs except for the two models on Germany, and they are statistically significant in the UK and France models in Table 2 and economic aid and total aid models in Table 3. There is no evidence that donors will increase aid to prospective allies during the negotiation period or use aid to attract allies. In fact, the opposite might be true. Donors

22 The sanction was lifted immediately after the September 11 attacks. See "Sanctions on India and Pakistan", Office of the Spokeman, September 22, 2001. Links: https://2001-2009.state.gov/r/pa/prs/ps/2001/5101.htm. 
Please do not circulate or cite without permission of the author.

would reduce aid when negotiating alliance terms. It is likely that the attraction mechanism is at work. Donors may use alliance, alongside or instead of aid, as an incentive to solicit policy concessions from potential small allies.
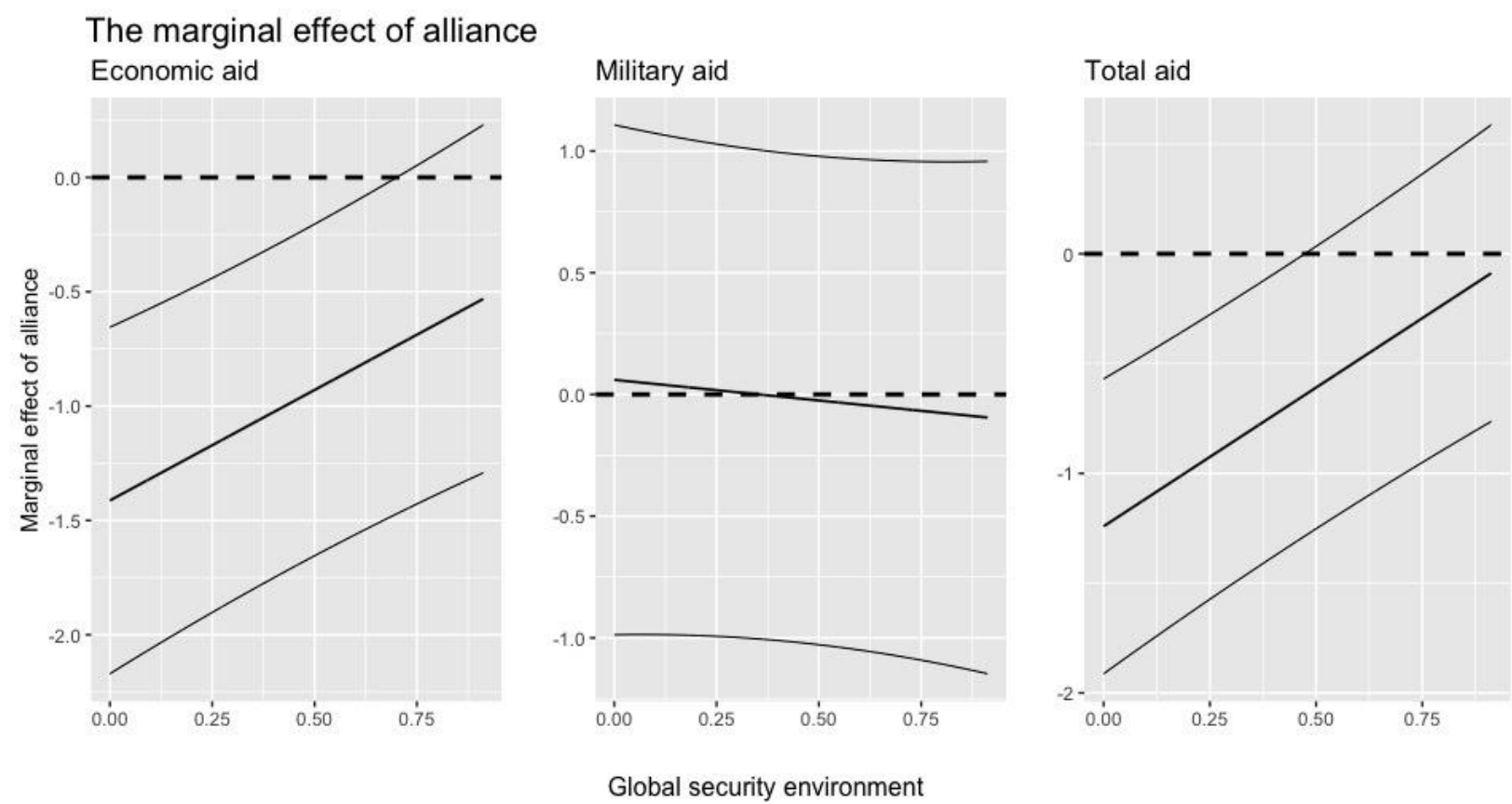
Please do not circulate or cite without permission of the author.

Table 4: Robustness check with Greenbook aid data

\begin{tabular}{|c|c|c|c|c|c|c|}
\hline & \multicolumn{6}{|c|}{ Dependent variable: greenbook aid } \\
\hline & \multicolumn{3}{|c|}{ Military personnel measure of GSE } & \multicolumn{3}{|c|}{ Military spending measure of GSE } \\
\hline & Economic aid & Military aid & Total aid & Economic aid & Military aid & total aid \\
\hline Alliance*GSE & $\begin{array}{c}0.966^{*} \\
(0.518)\end{array}$ & $\begin{array}{l}-0.170 \\
(0.603)\end{array}$ & $\begin{array}{c}1.263^{* * *} \\
(0.438)\end{array}$ & $\begin{array}{c}1.602 \\
(1.218)\end{array}$ & $\begin{array}{l}-0.506 \\
(1.368)\end{array}$ & $\begin{array}{l}2.311^{* *} \\
(1.032)\end{array}$ \\
\hline Alliance & $\begin{array}{c}-1.413^{*} \\
(0.734)\end{array}$ & $\begin{array}{c}0.060 \\
(0.843)\end{array}$ & $\begin{array}{c}-1.241^{*} \\
(0.714)\end{array}$ & $\begin{array}{c}-1.325^{*} \\
(0.744)\end{array}$ & $\begin{array}{c}0.069 \\
(0.836)\end{array}$ & $\begin{array}{l}-1.157 \\
(0.718)\end{array}$ \\
\hline Population & $\begin{array}{l}-1.027 \\
(1.000)\end{array}$ & $\begin{array}{c}0.471 \\
(1.285)\end{array}$ & $\begin{array}{l}-0.851 \\
(0.904)\end{array}$ & $\begin{array}{l}-0.952 \\
(1.027)\end{array}$ & $\begin{array}{c}0.512 \\
(1.269)\end{array}$ & $\begin{array}{c}-0.800 \\
(0.923)\end{array}$ \\
\hline Polity2 & $\begin{array}{c}-0.0002 \\
(0.022)\end{array}$ & $\begin{array}{c}0.037 \\
(0.028)\end{array}$ & $\begin{array}{l}0.0003 \\
(0.017)\end{array}$ & $\begin{array}{c}0.001 \\
(0.022)\end{array}$ & $\begin{array}{c}0.036 \\
(0.028)\end{array}$ & $\begin{array}{c}0.003 \\
(0.016)\end{array}$ \\
\hline GDP per capita & $\begin{array}{l}-0.507 \\
(0.321)\end{array}$ & $\begin{array}{c}0.006 \\
(0.393)\end{array}$ & $\begin{array}{l}-0.242 \\
(0.301)\end{array}$ & $\begin{array}{l}-0.510 \\
(0.320)\end{array}$ & $\begin{array}{c}0.004 \\
(0.393)\end{array}$ & $\begin{array}{c}-0.244 \\
(0.300)\end{array}$ \\
\hline UNSC & $\begin{array}{l}-0.070 \\
(0.176)\end{array}$ & $\begin{array}{c}0.161 \\
(0.291)\end{array}$ & $\begin{array}{l}-0.030 \\
(0.154)\end{array}$ & $\begin{array}{l}-0.073 \\
(0.176)\end{array}$ & $\begin{array}{c}0.162 \\
(0.291)\end{array}$ & $\begin{array}{l}-0.035 \\
(0.154)\end{array}$ \\
\hline UN voting & $\begin{array}{l}-0.315 \\
(0.251)\end{array}$ & $\begin{array}{c}-2.391^{* * *} \\
(0.568)\end{array}$ & $\begin{array}{c}-0.383^{*} \\
(0.228)\end{array}$ & $\begin{array}{c}-0.324 \\
(0.253)\end{array}$ & $\begin{array}{c}-2.410^{* * *} \\
(0.580)\end{array}$ & $\begin{array}{c}-0.383^{*} \\
(0.229)\end{array}$ \\
\hline aid at t-1 & $\begin{array}{c}0.466^{* * *} \\
(0.042)\end{array}$ & $\begin{array}{c}0.447^{* * *} \\
(0.067)\end{array}$ & $\begin{array}{c}0.502^{* * * *} \\
(0.043)\end{array}$ & $\begin{array}{c}0.467^{* * *} \\
(0.042)\end{array}$ & $\begin{array}{c}0.447^{* * *} \\
(0.067)\end{array}$ & $\begin{array}{c}0.504^{* * *} \\
(0.043)\end{array}$ \\
\hline Negotiation & $\begin{array}{c}-1.242^{* * *} \\
(0.455)\end{array}$ & $\begin{array}{c}-1.031^{*} \\
(0.615)\end{array}$ & $\begin{array}{c}-1.098^{* *} \\
(0.445)\end{array}$ & $\begin{array}{c}-1.267^{* * *} \\
(0.470)\end{array}$ & $\begin{array}{l}-1.050 \\
(0.637)\end{array}$ & $\begin{array}{c}-1.119^{* *} \\
(0.461)\end{array}$ \\
\hline Export to donor & $\begin{array}{c}0.033 \\
(0.080)\end{array}$ & $\begin{array}{c}0.034 \\
(0.105)\end{array}$ & $\begin{array}{c}0.038 \\
(0.073)\end{array}$ & $\begin{array}{c}0.108 \\
(0.099)\end{array}$ & $\begin{array}{c}0.135 \\
(0.133)\end{array}$ & $\begin{array}{l}0.152^{*} \\
(0.086)\end{array}$ \\
\hline Import from donor & $\begin{array}{c}0.033 \\
(0.080)\end{array}$ & $\begin{array}{c}0.035 \\
(0.105)\end{array}$ & $\begin{array}{c}0.036 \\
(0.073)\end{array}$ & $\begin{array}{c}0.033 \\
(0.081)\end{array}$ & $\begin{array}{c}0.035 \\
(0.105)\end{array}$ & $\begin{array}{c}0.036 \\
(0.073)\end{array}$ \\
\hline Year FE & yes & yes & yes & yes & yes & yes \\
\hline Unit FE & yes & yes & yes & yes & yes & yes \\
\hline Observations & 5,600 & 5,600 & 5,600 & 5,574 & 5,574 & 5,574 \\
\hline $\mathrm{R}^{2}$ & 0.818 & 0.737 & 0.798 & 0.814 & 0.736 & 0.791 \\
\hline Adjusted $\mathrm{R}^{2}$ & 0.811 & 0.727 & 0.790 & 0.807 & 0.725 & 0.782 \\
\hline Residual Std. Error & $2.479(\mathrm{df}=5387)$ & $3.420(\mathrm{df}=5387)$ & $2.197(\mathrm{df}=5387)$ & $2.485(\mathrm{df}=5363)$ & $3.426(\mathrm{df}=5363)$ & $2.203(\mathrm{df}=5363)$ \\
\hline
\end{tabular}




\section{CONCLUSION}

This essay starts with the empirical puzzle of why allies of a major power receive less foreign aid than other recipients. Traditionally, scholars believe donors provide more aid to allies to meet their security needs and to strengthen the alliance. More recently, scholars have noticed that alliance does not always increase foreign aid allocation. However, existing studies did not delve deeper and explain the changing relationship between alliance and aid over time. This article shows that the meaning of alliance has changed since the end of the Cold War. It argues that alliance's impact on foreign aid allocation is conditional on the security environment. When the security environment is favorable to the donor, it is likely to use alliance as leverage to solicit policy concessions, which would then save the donor's aid budget. Alliance is also a valuable asset to aid receiving countries, and thus, they are willing to comply with donors' demand in order to join the alliance. When the security environment becomes more competitive, alliance with the donor will be both an asset and a liability, because small allies might be involved in major power competition. Therefore, donors need to provide more foreign aid to strengthen the alliance and to support the friendly regime. The foreign aid literature tends to use alliance as an indicator of strategic significance. This article would argue this confuses the cause and consequence. A donor would like to ally with a recipient for the same reason why it would provide more aid to the recipient: donors would like to ally with a state because it is important for the donor's strategic goal. Both alliance and foreign aid are foreign policy tools at the major power's disposal.

There are two areas of future research. First, this article does not directly test the attraction and substitution mechanisms. The decline in aid during the negotiation period suggests that the attraction mechanism is at work. Empirical research on NATO also finds that the aspiration to join alliance encouraged Central and Eastern European states to conduct market and political reforms and contribute troops to the US and EU-led military operations. This is one piece of evidence supporting the attraction mechanism. However, the attraction mechanism, by encouraging aspiring members to conduct structural reforms, can also reduce aid in the long run. The attraction effect and substitution effect can coexist, and thus, are hard to separate. We can, however, test these two mechanisms by studying cases where only the substitution or the attraction mechanism works. Secondly, due to data availability, it does not test how foreign aid allocation might evolve due to the rise of China. Since 2012 the Sino-Japanese territorial dispute, China has been increasingly at conflict with the West, and in particular, the United States. As China becomes a qualified rival to the United States, it would be interesting to see how the US's foreign aid allocation changes. 
Please do not circulate or cite without permission of the author. 


\section{BIBLIOGRAPHY}

Adcock, Robert, and David Collier. 2001. "Measurement Validity: A Shared Standard for Qualitative and Quantitative Research." American Political Science Review 95(3): 52946.

Albalate, Daniel, Germà Bel, and Ferran Elias. 2012. "Institutional Determinants of Military Spending." Journal of Comparative Economics 40(2): 279-90.

Alesina, Alberto, and David Dollar. 2000. "Alesina, Alberto, and David Dollar. "Who Gives Foreign Aid to Whom and Why?" Journal of Economic Growth 5(1): 33-63.

Art, Robert J. 1991. "A Defensible Defense: America's Grand Strategy after the Cold War." International Security 15(4): 5.

Baron, Reuben M, and David A Kenny. 1986. "The Moderator-Mediator Variable Distinction in Social Psychological Research: Conceptual, Strategic, and Statistical Considerations." Journal of Personality and Social Psychology 51: 1173-82.

Bearce, David H., and Daniel C. Tirone. 2010. "Foreign Aid Effectiveness and the Strategic Goals of Donor Governments." The Journal of Politics 72(3): 837-51.

Bollen, Kenneth A. 1989. "A New Incremental Fit Index for General Structural Equation Models." Sociological Methods \& Research 17(3): 303-16.

Brinkley, Douglas. 1997. "Democratic Enlargement: The Clinton Doctrine." Foreign Policy 106(Spring): 110-27.

Bruce Bueno de Mesquita. 2009. "A Political Economy of Aid." International Organization 63(2): 309-40.

Choi, Ajin. 2012. "Fighting to the Finish: Democracy and Commitment in Coalition War." Security Studies 21(4): 624-53.

Clarke, Simon, Chang-Hee Lee, and Qi Li. 2004. "Collective Consultation and Industrial Relations in China." British Journal of Industrial Relations 42(2): 235-54.

David Dollar, Victoria Levin. 2006. "The Increasing Selectivity of Foreign Aid, 1984-2003." World Development 34(12): 2034-46.

Desha M. Girod. 2012. "Effective Foreign Aid Following Civil War: The Nonstrategic-Desperation Hypothesis." American Journal of Political Science 56(1): 188-201.

Dueck, Colin. 2004. "Ideas and Alternatives in American Grand Strategy, 2000-2004." Review of International Studies 30(4): 511-35. 
Please do not circulate or cite without permission of the author.

Dunne, J. Paul, and Nadir A. L. Mohammed. 1995. "Military Spending in Sub-Saharan Africa: Some Evidence for 1967-85." Journal of Peace Research 32(3): 331-43.

Dunning, Thad. 2004. "Conditioning the Effects of Aid: Cold War Politics, Donor Credibility, and Democracy in Africa." International Organization 58(02). http://www.journals.cambridge.org/abstract_S0020818304582073 (June 22, 2019).

Epstein, Rachel A. 2005. "Nato Enlargement and the Spread of Democracy: Evidence and Expectations." Security Studies 14(1): 63-105.

Fazal, Tanisha M. 2014. “Dead Wrong?: Battle Deaths, Military Medicine, and Exaggerated Reports of War's Demise." International Security 39(1): 95-125.

Fleck, Robert K., and Christopher Kilby. 2010. "Changing Aid Regimes? U.S. Foreign Aid from the Cold War to the War on Terror." Journal of Development Economics 91(2): 185-97.

Gheciu, Alexandra. 2005. "Security Institutions as Agents of Socialization? NATO and the 'New Europe.'" International Organization 59(04). http://www.journals.cambridge.org/abstract_S0020818305050332 (March 22, 2020).

Gibler, Douglas M., and Scott Wolford. 2006. "Alliances, Then Democracy: An Examination of the Relationship between Regime Type and Alliance Formation." Journal of Conflict Resolution 50(1): 129-53.

Gibler, Douglas, and Toby Rider. 2004. "Prior Commitments: Compatible Interests versus Capabilities in Alliance Behavior." International Interactions 30(4): 309-29.

Glaser, Charles L. 1997. "The Security Dilemma Revisited." World Politics 50: 171-201.

Goldgeier, James. 1999. Not Whether but When: The US Decision to Enlarge NATO. Washington DC: Brookings Institution Press.

Heinrich, Tobias. 2013. "When Is Foreign Aid Selfish, When Is It Selfless?" The Journal of Politics 75(2): 422-35.

Herz, John H. 1950. "Idealist Internationalism and the Security Dilemma." World Politics 2(2): 157-80.

Hewitt, Daniel P. 1993. Military Expenditures 1972-1990: The Reasons Behind the Post-1985 Fall in World Military Spending. Washington DC: International Monetary Fund.

Hoeffler, Anke, and Verity Outram. 2011. "Need, Merit, or Self-Interest-What Determines the Allocation of Aid?: WHAT DETERMINES THE ALLOCATION OF AID?" Review of Development Economics 15(2): 237-50. 
Please do not circulate or cite without permission of the author.

Hout, Wil. 2002. "Good Governance and Aid: Selectivity Criteria in Development Assistance." Development and change 33(3).

Houthakker, H. S. 1950. "Revealed Preference and the Utility Function." Economica 17(66): 159.

Ikenberry, G. John. 2011. "The Future of the Liberal World Order: Internationalism After America." Foreign Affairs 90(3): 56-68.

Ikenberry, John G. 2001. "American Grand Strategy in the Age of Terror." Survival 43(4): 19-34.

Imai, Kosuke, and In Song Kim. 2016. "When Should We Use Linear Fixed Effects Regression Models for Causal Inference with Longitudinal Data?" : 57.

Jervis, Robert. 1978. "Cooperation under the Security Dilemma." World Politics 30(2): 167-214.

- - . 1997. "Complexity and the Analysis of Political and Social Life." Political Science Quarterly 112(4): 569.

- - . 2001. "Was the Cold War a Security Dilemma?" Journal of Cold War Studies 3(1): 36-60.

- - - 2017. "Perception and the Level of Analysis Problem." In Perception and Misperception in International Politics, Princeton, N.J.: Princeton University Press, 544.

Kinne, Brandon J. 2018. "Defense Cooperation Agreements and the Emergence of a Global Security Network." International Organization 72(4): 799-837.

Kinne, Brandon J. 2020. "The Defense Cooperation Agreement Dataset (DCAD)." Journal of Conflict Resolution 64(4): 729-55.

Lacina, Bethany, and Nils Petter Gleditsch. 2005. "Monitoring Trends in Global Combat: A New Dataset of Battle Deaths." European Journal of Population / Revue européenne de Démographie 21(2-3): 145-66.

Lake, Anthony. 1993. "From Containment to Enlargement." Department of State Dispatch 658: 8.

Maizels, Alfred, and Machiko K. Nissanke. 1986. "The Determinants of Military Expenditures in Developing Countries." World Development 14(9): 1125-40.

Mastanduno, Michael. 1997. "Preserving the Unipolar Moment." International Security 21(4): 49-88.

McGillivray, Mark. 2003. "Modelling Aid Allocation: Issues, Approaches and Results." WIDER Discussion Papers/World Institute for Development Economics.

Meernik, James, Eric L. Krueger, and Steven C. Poe. 1998. "Testing Models of U.S. Foreign Policy: Foreign Aid during and after the Cold War." The Journal of Politics 60(1): 63-85. 
Please do not circulate or cite without permission of the author.

Monteiro, Nuno P. 2012. "Unrest Assured: Why Unipolarity Is Not Peaceful." International Security 36(3): 9-40.

Morgenthau, Hans. 1962. "A Political Theory of Foreign Aid." American Political Science Review 56(2): 301-9.

Munck, Gerardo L., and Jay Verkuilen. 2002. "Conceptualizing and Measuring Democracy: Evaluating Alternative Indices." Comparative Political Studies 35(1): 5-34.

Peter J. Schraeder, Steven W. Hook, Bruce Taylor. 2011. "Clarifying the Foreign Aid Puzzle: A Comparison of American, Japanese, French, and Swedish Aid Flows." World Politics 50(2): 294-323.

Pilster, Ulrich. 2011. "Are Democracies the Better Allies? The Impact of Regime Type on Military Coalition Operations." International Interactions 37(1): 55-85.

Pinker, Steven. 2011. The Better Angels of Our Nature: Why Violence Has Declined. London, England.

Poe, Poe, Steven C., and James Meernik. 1995. "US Military Aid in the 1980s: A Global Analysis." Journal of Peace Research 32(4): 399-411.

Randall W. Stone. 2006. "Buying Influence: The Political Economy of International Aid." In San Diego.

Rudloff, Peter, James M Scott, and Tyra Blew. 2013. "Countering Adversaries and Cultivating Friends: Indirect Rivalry Factors and the Allocation of US Foreign Aid." Cooperation and Conflict 48(3): 401-23.

Samuelson, Paul A. 1948. "Consumption Theory in Terms of Revealed Preference." Economica 15(60): 243.

Sarah Blodgett Bermeo. 2017. "Aid Allocation and Targeted Development in an Increasingly Connected World." International Organization 71(4): 735-66.

Schneider, Christina J., and Jennifer L. Tobin. 2013. "Interest Coalitions and Multilateral Aid Allocation in the European Union." International Studies Quarterly 57(1): 103-14.

Singer, J. David, Stuart Bremer, and John Stuckey. 1972. "Capability Distribution, Uncertainty, and Major Power War, 1820-1965." In Peace, War, and Numbers, Beverly Hills: Sage.

Solarin, Sakiru Adebola. 2018. "Determinants of Military Expenditure and the Role of Globalisation in a Cross-Country Analysis." Defence and Peace Economics 29(7): 853-70. 
Please do not circulate or cite without permission of the author.

Tago, A. 2006. "Why Do States Join US-Led Military Coalitions?: The Compulsion of the Coalition's Missions and Legitimacy." International Relations of the Asia-Pacific 7(2): 179-202.

Tang, Shiping. 2009. "The Security Dilemma: A Conceptual Analysis." Security Studies 18(3): 587-623.

Tierney, Michael J. et al. 2011. "More Dollars than Sense: Refining Our Knowledge of Development Finance Using AidData." World Development 39(11): 1891-1906.

Vucetic, Srdjan. 2011. "Bound to Follow? The Anglosphere and US-Led Coalitions of the Willing, 1950-2001." European Journal of International Relations 17(1): 27-49.

Walt, Stephen. 1990. The Origines of Alliances. Ithaca and London: Cornell University Press.

Walt, Stephen M. 2018. "US Grand Strategy after the Cold War: Can Realism Explain It? Should Realism Guide It?" International Relations 32(1): 3-22.

Waltz, Kenneth N. 1979. Theory of International Politics. Addison-Wesley Publishing Company.

Waterman, Harvey, Dessie Zagorcheva, and Dan Reiter. 2002. "NATO and Democracy." International Security 26(3): 221-35.

Wendt, Alexander. 1992. "Anarchy Is What States Make of It: The Social Construction of Power Politics." International Organization 46(2): 391-425.

Wolford, Scott. 2015. The Politics of Military Coalitions. Cambridge: Cambridge University Press. http://ebooks.cambridge.org/ref/id/CBO9781316179154 (March 18, 2020). 


\section{Appendix 1}

Table 1: summary of variables by alliance status $\quad(\mathrm{N}=\mathbf{2 0 5 6 0})$

\begin{tabular}{|c|c|c|c|c|}
\hline Variables & Explanation & Overall & Allies & Non-allies \\
\hline Total N & dyad-year observations & 20560 & 1920 & 18640 \\
\hline Number of recipient & & 160 & 58 & 102 \\
\hline United States & & 160 & 48 & 112 \\
\hline France & & 160 & 22 & 138 \\
\hline United Kingdom & & 160 & 15 & 145 \\
\hline Germany & & 160 & 11 & 149 \\
\hline military spending & $\begin{array}{l}\text { global military spending as a percent of GDP, } \% \\
\text { number of military personnel per million people at time } t \text {, global }\end{array}$ & $3.21(0.63)$ & & \\
\hline military personnel & average & $4.84(1.44)$ & & \\
\hline population & Recipient population at time $t$, natural $\log$ & $15.43(2.04)$ & $15.43(2.04)$ & $15.41(2.08)$ \\
\hline polity2 & polity 2 score of a recipient at time $t$ & $-0.79(7.09)$ & $-1.15(6.96)$ & $2.66(7.42)$ \\
\hline Real GDP & real GDP of a recipient at time $\mathrm{t}$ & $9.83(2.04)$ & $9.77(2.01)$ & $10.41(2.22)$ \\
\hline GDP per capita & GDP per capita of a recipient at time $t$, natural log & $8.22(1.01)$ & $8.16(1.01)$ & $8.82(0.80)$ \\
\hline UN voting & $\begin{array}{l}\text { UN voting distance between a recipient a donor at time } t \\
\text { Aid from a donor to a recipient at time } t \text {, natural log of } 3 \text {-year }\end{array}$ & $2.24(0.83)$ & $2.24(0.81)$ & $2.30(0.99)$ \\
\hline aid & average & $11.47(6.82)$ & $11.36(6.76)$ & $12.58(7.30)$ \\
\hline distcap & $\begin{array}{l}\text { Geographical distance between the capitals of the donor and } \\
\text { recipient }\end{array}$ & $\begin{array}{l}7278.74 \\
(3481.21)\end{array}$ & $\begin{array}{l}7544.32 \\
(3405.04)\end{array}$ & $\begin{array}{l}4700.42 \\
(3143.77)\end{array}$ \\
\hline colony & Whether a recipient was a colony of the donor & $0.14(0.35)$ & $0.15(0.35)$ & $0.13(0.33)$ \\
\hline EU member & Whether the recipient is a EU member at time $\mathrm{t}$ & $0.01(0.09)$ & $0.00(0.03)$ & $0.07(0.26)$ \\
\hline $\begin{array}{l}\text { UN Security } \\
\text { Council }\end{array}$ & $\begin{array}{l}\text { Whether the recipient is a member of the UN Security Council at } \\
\text { time } t\end{array}$ & $0.05(0.23)$ & $0.05(0.22)$ & $0.07(0.25)$ \\
\hline
\end{tabular}




\section{Appendix 2: robustness check with pooled analysis}

While the main model, with its two-way fixed effects, gives us more confidence in addressing omitted variable bias, it has one disadvantage. The unit (dyad) fixed effect controls out variance across dyads. Take the simplest fixed effect model (equation 3) for example. Wherein is the unit fixed effect, and represents alliance status. To estimate the parameters for each unit $i$, we take away the mean over $i$, and the equation can be rewritten as equation 4 ).

If the alliance status does not change over time, this part of the variance will not be taken into account. This is to say the model will treat the dyads that are long-term allies and the dyads that have never had alliance the same. Many of existing alliances were established during the Second World War or shortly after that, but foreign aid only became a popular policy tool in the late 1960s and early 1970s. Neglecting these cases limits our ability to examine all defensive alliances and our confidence to generalize our findings. For this reason, I include the second group of models with time fixed effect but not unit fixed effect. To cope with potential heterogeneity, I will include two additional control variables that measure bilateral relationsdistance between a donor and a given recipient and whether they have colonial ties. The results are as follows:

\begin{tabular}{|c|c|c|c|c|c|c|c|c|}
\hline & \multicolumn{8}{|c|}{ Dependent variable:ODA aid } \\
\hline & \multicolumn{4}{|c|}{ Military personnel measure of GSE } & \multicolumn{4}{|c|}{ Military spending measure of GSE } \\
\hline & United States & United Kingdom & France & Germany & United States & United Kingdom & France & Germany \\
\hline Alliance & $\begin{array}{c}-1.859^{* *} \\
(0.728)\end{array}$ & $\begin{array}{c}-5.219^{* * *} \\
(1.075)\end{array}$ & $\begin{array}{c}-2.191^{* * *} \\
(0.694)\end{array}$ & $\begin{array}{c}-3.680^{* * *} \\
(1.385)\end{array}$ & $\begin{array}{c}-2.125^{* * *} \\
(0.819)\end{array}$ & $\begin{array}{c}-4.877^{* * *} \\
(1.254)\end{array}$ & $\begin{array}{l}-1.799^{* *} \\
(0.747)\end{array}$ & $\begin{array}{c}-3.162^{* *} \\
(1.382)\end{array}$ \\
\hline Alliance*GSE & $\begin{array}{r}1.789^{* * *} \\
(0.687)\end{array}$ & $\begin{array}{c}6.715^{* * *} \\
(1.845)\end{array}$ & $\begin{array}{c}5.752^{* * *} \\
(1.093)\end{array}$ & $\begin{array}{c}10.462^{* * *} \\
(3.801)\end{array}$ & $\begin{array}{l}1.765^{* *} \\
(0.783)\end{array}$ & $\begin{array}{c}7.500^{* * *} \\
(1.492)\end{array}$ & $\begin{array}{c}6.002^{* * *} \\
(0.913)\end{array}$ & $\begin{array}{l}8.357^{* *} \\
(3.261)\end{array}$ \\
\hline Population & $\begin{array}{r}0.568^{* *} \\
(0.151)\end{array}$ & $\begin{array}{c}0.082 \\
(0.139)\end{array}$ & $\begin{array}{c}0.050 \\
(0.165)\end{array}$ & $\begin{array}{r}0.867^{* * *} \\
(0.139)\end{array}$ & $\begin{array}{c}0.702^{* *} \\
(0.153)\end{array}$ & $\begin{array}{l}0.279^{*} \\
(0.146)\end{array}$ & $\begin{array}{l}0.257^{*} \\
(0.124)\end{array}$ & $\begin{array}{r}0.832^{* * *} \\
(0.144)\end{array}$ \\
\hline Distance & $\begin{array}{c}-0.00001 \\
(0.0001)\end{array}$ & $\begin{array}{l}0.0003^{* *} \\
(0.0001)\end{array}$ & $\begin{array}{c}-0.00003 \\
(0.0001)\end{array}$ & $\begin{array}{c}0.0001 \\
(0.0001)\end{array}$ & $\begin{array}{c}-0.00002 \\
(0.0001)\end{array}$ & $\begin{array}{l}0.0003^{* *} \\
(0.0001)\end{array}$ & $\begin{array}{l}0.00001 \\
(0.0001)\end{array}$ & $\begin{array}{l}0.0002^{*} \\
(0.0001)\end{array}$ \\
\hline polity2 score & $\begin{array}{c}0.056^{+*} \\
(0.018)\end{array}$ & $\begin{array}{l}0.039^{*} \\
(0.022)\end{array}$ & $\begin{array}{c}0.011 \\
(0.020)\end{array}$ & $\begin{array}{c}0.028 \\
(0.019)\end{array}$ & $\begin{array}{l}0.046^{* *} \\
(0.021)\end{array}$ & $\begin{array}{c}0.006 \\
(0.023)\end{array}$ & $\begin{array}{c}0.029 \\
(0.019)\end{array}$ & $\begin{array}{c}0.030 \\
(0.020)\end{array}$ \\
\hline GDP per capita & $\begin{array}{c}-1.007^{* *} \\
(0.231)\end{array}$ & $\begin{array}{c}-1.940^{* * *} \\
(0.258)\end{array}$ & $\begin{array}{c}-0.836^{* * *} \\
(0.231)\end{array}$ & $\begin{array}{c}-1.158^{* * *} \\
(0.201)\end{array}$ & $\begin{array}{c}-0.922^{* * *} \\
(0.232)\end{array}$ & $\begin{array}{c}-1.697^{* * *} \\
(0.279)\end{array}$ & $\begin{array}{c}-0.537^{\cdots *} \\
(0.181)\end{array}$ & $\begin{array}{c}-1.077^{* * *} \\
(0.204)\end{array}$ \\
\hline UNSC & $\begin{array}{c}0.121 \\
(0.269)\end{array}$ & $\begin{array}{l}-0.326 \\
(0.268)\end{array}$ & $\begin{array}{l}-0.370^{\circ} \\
(0.200)\end{array}$ & $\begin{array}{l}-0.061 \\
(0.291)\end{array}$ & $\begin{array}{l}-0.266 \\
(0.323)\end{array}$ & $\begin{array}{l}-0.518 \\
(0.330)\end{array}$ & $\begin{array}{l}-0.417^{*} \\
(0.220)\end{array}$ & $\begin{array}{l}-0.279 \\
(0.387)\end{array}$ \\
\hline ODA aid at $\mathrm{t}-1$ & $\begin{array}{r}0.494^{* *} \\
(0.025)\end{array}$ & $\begin{array}{r}0.457^{*} \cdots \\
(0.023)\end{array}$ & $\begin{array}{r}0.493^{* *} \\
(0.027)\end{array}$ & $\begin{array}{r}0.391^{* *} \\
(0.024)\end{array}$ & $\begin{array}{r}0.484^{* *} \\
(0.030)\end{array}$ & $\begin{array}{c}0.480^{* * *} \\
(0.025)\end{array}$ & $\begin{array}{r}0.456^{* *} \\
(0.028)\end{array}$ & $\begin{array}{c}0.378^{* *} \\
(0.026)\end{array}$ \\
\hline UN voting & $\begin{array}{c}-1.196^{* *} \\
(0.261)\end{array}$ & $\begin{array}{l}-0.264 \\
(0.306)\end{array}$ & $\begin{array}{c}0.033 \\
(0.257)\end{array}$ & $\begin{array}{c}-0.748^{* * *} \\
(0.256)\end{array}$ & $\begin{array}{c}-0.915^{* *} \\
(0.318)\end{array}$ & $\begin{array}{c}0.313 \\
(0.346)\end{array}$ & $\begin{array}{l}0.540^{* *} \\
(0.262)\end{array}$ & $\begin{array}{l}-0.041 \\
(0.313)\end{array}$ \\
\hline EU member & $\begin{array}{c}-6.474^{\cdots *} \\
(0.939)\end{array}$ & $\begin{array}{c}-2.309^{* *} \\
(1.030)\end{array}$ & $\begin{array}{c}-5.579^{* * *} \\
(0.927)\end{array}$ & $\begin{array}{c}-3.719^{* * *} \\
(1.277)\end{array}$ & $\begin{array}{c}-5.793^{* * *} \\
(1.053)\end{array}$ & $\begin{array}{c}-3.006^{* * *} \\
(1.033)\end{array}$ & $\begin{array}{c}-6.303^{* * *} \\
(0.946)\end{array}$ & $\begin{array}{c}-4.895^{* * *} \\
(1.178)\end{array}$ \\
\hline Negotiation & $\begin{array}{l}-0.471 \\
(0.651)\end{array}$ & $\begin{array}{c}-1.961^{* *} \\
(0.890)\end{array}$ & $\begin{array}{l}-0.360 \\
(0.383)\end{array}$ & $\begin{array}{c}0.420 \\
(1.068)\end{array}$ & $\begin{array}{l}-0.380 \\
(0.617)\end{array}$ & $\begin{array}{c}-2.065^{* * *} \\
(0.780)\end{array}$ & $\begin{array}{l}-0.478 \\
(0.344)\end{array}$ & $\begin{array}{c}0.248 \\
(1.091)\end{array}$ \\
\hline Export to donor & $\begin{array}{l}-0.097 \\
(0.062)\end{array}$ & $\begin{array}{c}0.394^{\cdots} \\
(0.120)\end{array}$ & $\begin{array}{l}-0.148^{*} \\
(0.084)\end{array}$ & $\begin{array}{l}-0.082 \\
(0.095)\end{array}$ & $\begin{array}{l}-0.028 \\
(0.064)\end{array}$ & $\begin{array}{c}0.377^{* *} \\
(0.124)\end{array}$ & $\begin{array}{l}-0.071 \\
(0.066)\end{array}$ & $\begin{array}{l}-0.012 \\
(0.093)\end{array}$ \\
\hline Import from donor & $\begin{array}{l}0.295^{* *} \\
(0.126)\end{array}$ & $\begin{array}{l}0.322^{* *} \\
(0.144)\end{array}$ & $\begin{array}{c}0.702^{* *} \\
(0.144)\end{array}$ & $\begin{array}{c}0.147 \\
(0.124)\end{array}$ & $\begin{array}{c}0.098 \\
(0.115)\end{array}$ & $\begin{array}{c}0.148 \\
(0.132)\end{array}$ & $\begin{array}{c}0.433^{\cdots *} \\
(0.120)\end{array}$ & $\begin{array}{c}0.056 \\
(0.112)\end{array}$ \\
\hline Year FE & yes & yes & yes & yes & yes & yes & yes & yes \\
\hline Region FE & yes & yes & yes & yes & yes & yes & yes & yes \\
\hline Observations & 5,197 & 5,164 & 5,168 & 5,162 & 3,566 & 3,508 & 3,516 & 3,507 \\
\hline & 0.689 & 0.634 & 0.726 & 0.698 & 0.718 & 0.676 & 0.735 & 0.729 \\
\hline Residual Std. Error & $3.799(\mathrm{df}=5135)$ & $4.066(\mathrm{df}=5102)$ & $3.529(\mathrm{df}=5106)$ & $3.667(\mathrm{df}=5100)$ & $3.469(\mathrm{df}=3518)$ & $3.746(\mathrm{df}=3460)$ & $2.828(\mathrm{df}=3468)$ & $3.397(\mathrm{df}=3459)$ \\
\hline
\end{tabular}

